Rhode Island College

Digital Commons @ RIC

Master's Theses, Dissertations, Graduate

Master's Theses, Dissertations, Graduate Research and Major Papers Overview

Research and Major Papers

7-11-2021

\title{
African Muslim Slaves: Literacy and Arabic Narratives
}

Ruba Bouzan

Follow this and additional works at: https://digitalcommons.ric.edu/etd

Part of the English Language and Literature Commons

\section{Recommended Citation}

Bouzan, Ruba, "African Muslim Slaves: Literacy and Arabic Narratives" (2021). Master's Theses, Dissertations, Graduate Research and Major Papers Overview. 345.

https://digitalcommons.ric.edu/etd/345

This Thesis is brought to you for free and open access by the Master's Theses, Dissertations, Graduate Research and Major Papers at Digital Commons @ RIC. It has been accepted for inclusion in Master's Theses, Dissertations, Graduate Research and Major Papers Overview by an authorized administrator of Digital Commons @ RIC. For more information, please contact digitalcommons@ric.edu. 
AFRICAN MUSLIM SLAVES: LITERACY

\title{
AND ARABIC NARRATIVES
}

By Ruba Bouzan

\begin{abstract}
A Thesis Submitted in Partial Fulfillment
Of the Requirements for the Master of Arts in
\end{abstract}

The Department of English

The School of Art and Sciences

Rhode Island College

2021 


\begin{abstract}
This thesis examines African Muslim slaves and their Arabic writings that influenced their enslavement. The first part of my research considers the historical context that weaves two American presidents together with their distant interaction with Muslim slaves. It also discusses three prominent Muslim slaves in American history: Ayyub bin Suleiman, Abdul Rahman Ibrahima, and Omar ibn Said. Throughout the discussion of the lives of these three men, I analyze their Arabic writing and their use of mimicry throughout, and the ways in which this influenced their patrons' views of them. The second part explores their differing levels of Arabic literacy and how they were subject to varying degrees of Arabization and exoticization. The last part discusses the absence of their writing in the field of American literature and the American slave narrative genre while arguing for their inclusion in these areas.
\end{abstract}




\section{Table of Contents}

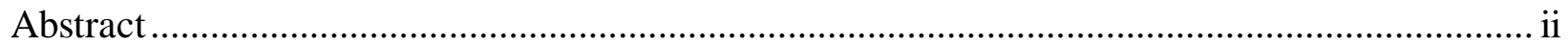

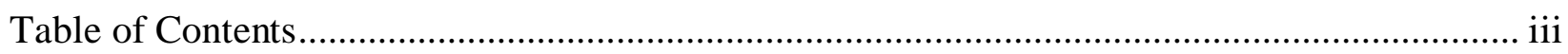

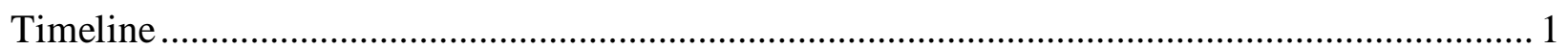

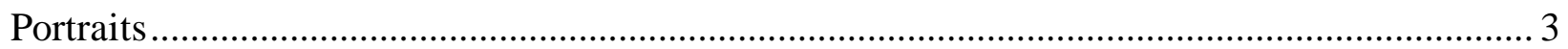

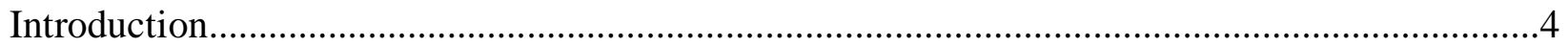

Chapter 1: Literacy, Muslims in early America, and the Role of America's Presidents............... 8

Chapter 2: Reading the Lives of Muslim Slaves and their Arabic Writing .............................. 16

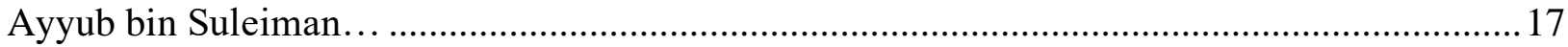

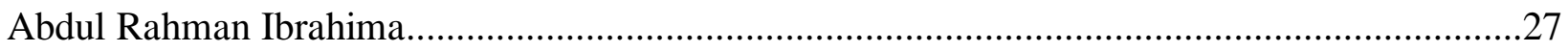

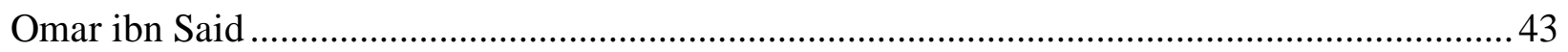

Chapter 3: Orientalizing and Arabizing Muslim Slaves..................................................... 63

Chapter 4: The Absence of Muslim Slave Writings in American and African American

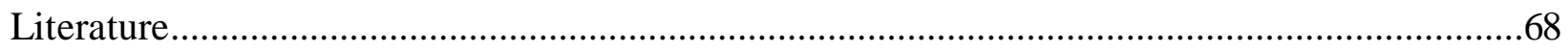

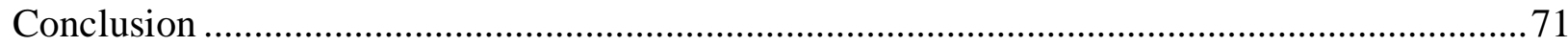

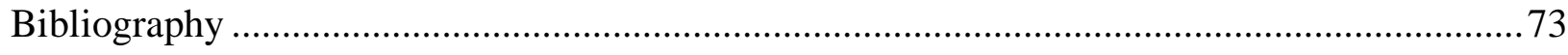

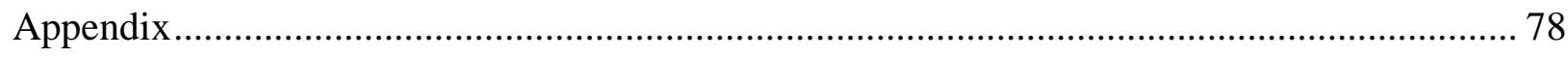




\section{Timeline}

1701: Ayyub bin Suleiman is born in Bundu.

1730: Captured by enemy Malinke tribe.

March 1: Arabella sets sail towards America.

1731: Ayyub arrives in Annapolis, Maryland and is purchased by Mr. Tolsey of Kent Island, Maryland.

Ayyub runs away from Mr. Tolsey’s plantation.

1731: June, captured and jailed in Kent County, Delaware.

Mr. Tolsey returns Ayyub to plantation and allows him to write a letter to his father.

1732: June, Mr. Denton buys Ayyub back from Mr. Tolsey due to his interest in his literacy.

1733: March, Ayyub sets sail for England with Thomas Bluett.

1734: Ayyub writes one of his three Qur'ans from memory.

June 6: Inducted into the Gentlemen's Society of Spalding.

Ayyub is officially freed from slavery.

July: Sails from England to Gambia.

1773: Ayyub dies in Bundu at the age of seventy-one.

1762: Abdul Rahman Ibrahima is born in Timbo.

1788: January, Abdul Rahman is captured by enemy Igbo and sold into slavery.

August 18: Abdul Rahman arrives in Natchez, Mississippi and is sold to Thomas Foster. 
1794: Abdul Rahman marries Isabella.

1803: Abdul Rahman meets Andrew Marschalk.

1807: Dr. Coates Cox crosses paths with Abdul Rahman in Natchez, Mississippi.

1821: Abdul Rahman visits Marschalk's printing office.

1826: Abdul Rahman writes a letter to the Moroccan consul.

1828: February 22, Abdul Rahman's deed is given to Andrew Marschalk by Thomas Foster.

Visits the White House and meets President John Quincy Adams.

1829: February 7, Abdul Rahman and his wife Arabella board the Harriett and sail to Liberia.

1829: July 6, Abdul Rahman dies at the age of sixty-seven.

1770: Omar ibn Said is born in Futa Toro.

1807: At the age of thirty-seven, Omar is enslaved and taken to Charleston, South Carolina.

1809: Omar escapes to Fayetteville, North Carolina.

Omar is jailed and bought by his new owner, General James Owen.

1831: Omar writes his fifteen-page autobiography.

1864: Omar dies in slavery at the age of 94 in North Carolina. 


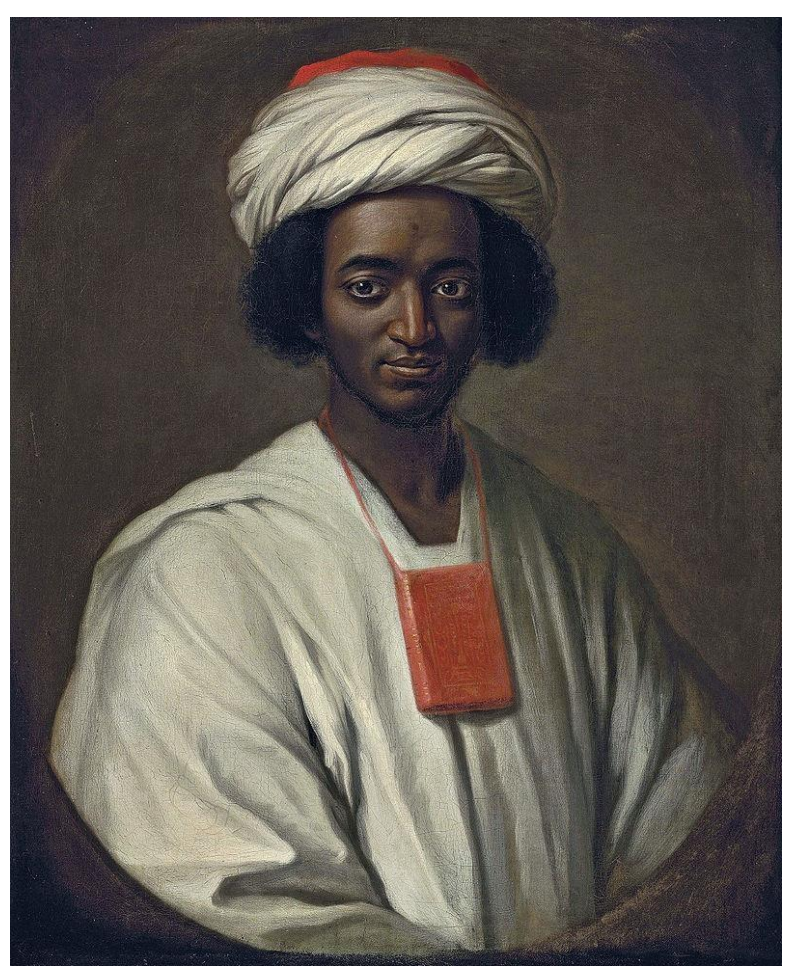

Ayyub bin Suleiman

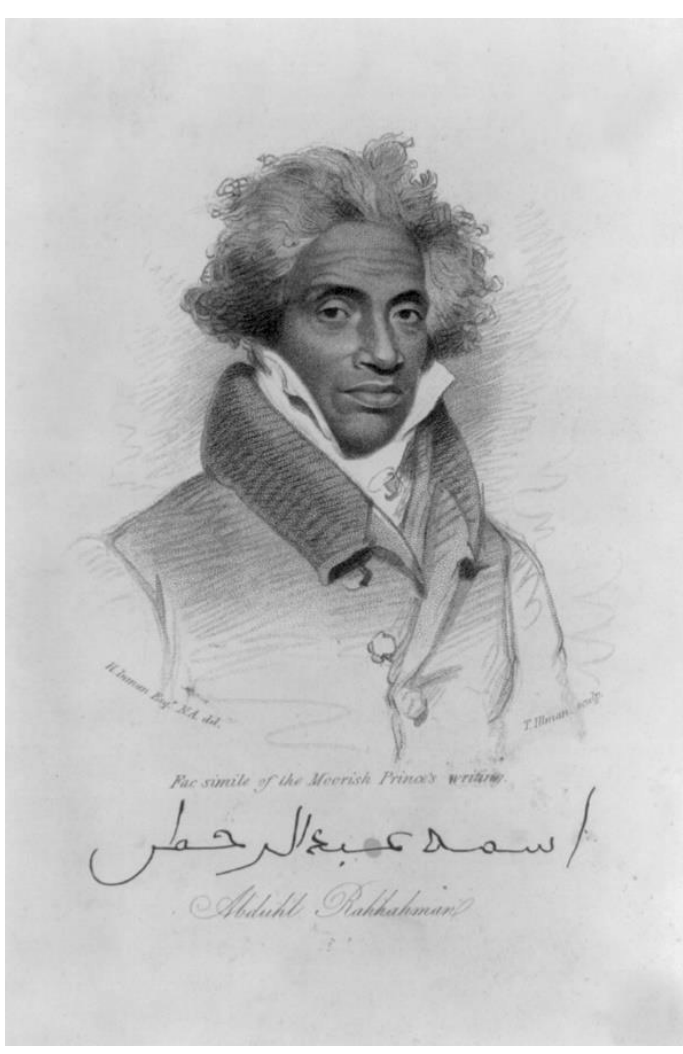

Abdul Rahman Ibrahima

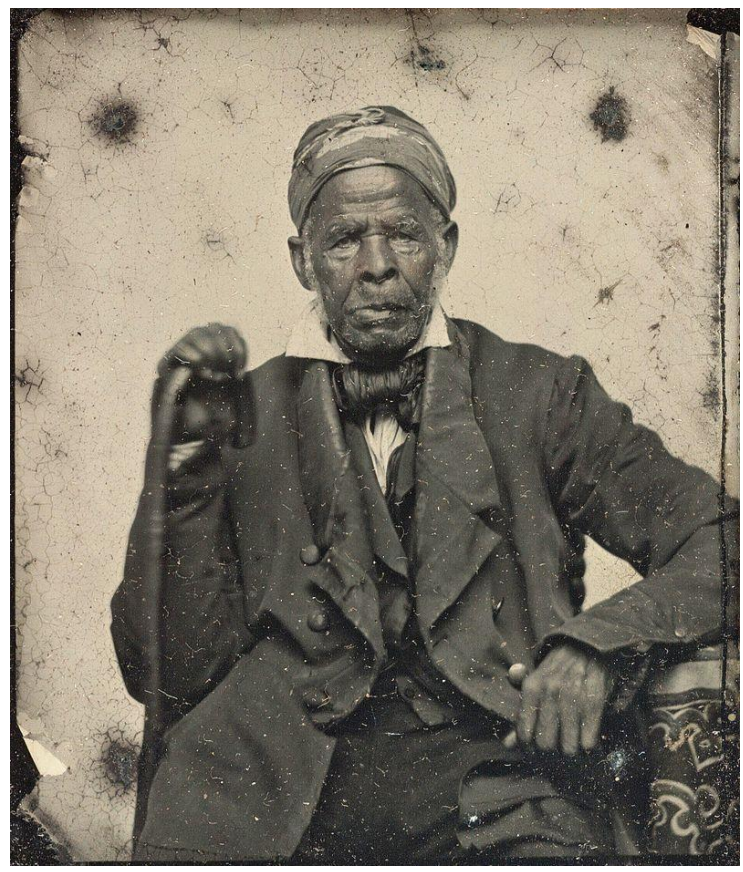

Omar ibn Said 


\section{Introduction}

The United States has had a long and complicated relationship with Islam. The presence of Islam and Arabic are largely seen as recent additions to North America, but history suggests otherwise. The trans-Atlantic slave trade introduced the West to Islam and the existence of Arabic literate slaves in the New World. Even more evident are the ties that the Arabic language had in relation to notable African slaves who gained fame because of the distinguishing quality of Arabic literacy. This evidence allows us to further examine Muslim slave writings and their beginnings in American literature. The best way to answer the question of what literacy generally meant to slaves in the United States is to look at the narrative of the most famous former U.S. slave, Frederick Douglass. Though his journey to literacy was different in comparison to the men who were literate in Arabic, his story of acquiring literacy follows a common trope in the U. S. slave narrative genre.

Douglass recalls his master Hugh Auld saying, "Learning would spoil the best $\mathrm{n}$ - in the world. Now, if you teach that n- how to read, there would be no keeping him. It would forever unfit him to be a slave. He would at once become unmanageable, and of no value to his master. As to himself, it could do him no good, but a great deal of harm. It would make him discontented and unhappy" (20). Hugh Auld here inadvertently gives Douglass the key to his freedom. Douglass knew that learning how to read would deliver him to freedom. After Frederick Douglass leaves the Great House Farm and arrives in Baltimore, he has to devise a new plan to learn after his lessons stop and his mistress, Sophia Auld, adopts the harsh ways of slavery. Cleverly, Douglass befriends the white boys who live on the same street. He uses every opportunity when sent on errands to find time for a lesson. Knowing that these white boys were only a notch above him in terms of freedom, Douglass writes, "I used to also carry bread with 
me, enough of which was always in the house, and to which I was always welcome; for I was much better off in this regard than many of the poor white children in our neighborhood. This bread I used to bestow upon the hungry little urchins, who in return, would give me the more valuable bread of knowledge" (Narrative 22). Douglass slowly learns how to write, using his earlier tactics of challenging the street children by way of proclaiming that he could also write. Fences, brick walls, and pavement became his copybooks, while chalk served as his pen and ink. Through these methods and long, tedious years, Douglass successfully learns how to write.

Douglass expresses that reading was a blessing and a curse and that his master was right. He was now very aware of his subordinate situation. However, slaves before Douglass knew how to read as well as write in Arabic prior to enslavement. Douglass could not yet read while he could at first write. Nonetheless, Douglass was at an advantage when he did learn how to read as he would be able to write himself passes that helped him to freedom. Unlike the enslaved men before him, Douglass relied mostly on his wit and English literacy and not on the sympathy of white patrons in his quest towards liberation. Like Douglass, slaves like Abdul Rahman Ibrahima relate their stories of how they demonstrated their literacy through what they had available. Sylviane Diouf writes that Ibrahima "traced the letters on the sand of his master's cotton plantation when the field hands were given a break" (Servants of Allah 111). According to Diouf, “sand writing was in all likelihood the most widespread technique used to preserve one's literacy_-" (Servants of Allah 111). Their reliance on a non-English language places them in a unique position.

Throughout my research I address the key figures who have risen to prominence through Arabic literacy including Abdul Rahman Ibrahima, who was dubbed the "Arab Prince," Ayyub bin Suleiman aka Job Ben Solomon, and Omar ibn Said. These enslaved men had a few things in 
common: they were literate, well educated, and practicing Muslims. For the most part, these men distinguished themselves from other slaves because of their literacy and education, which may have been the reason for their seemingly exceptional lives as enslaved people. What makes their narratives unique does not end simply at Arabic literacy but also when they acquired that literacy. Unlike former U.S. slave Frederick Douglass, they were literate in Arabic before their enslavement. They were also literate in their native languages. Compared to the narrative of Frederick Douglass, who essentially teaches himself how to read, their pre-slavery literacy is a key difference can provide a more comprehensive picture of the former narratives and expand our understanding of the American slave narrative genre.

Contrary to the attention paid to the way U.S.-born slaves acquired literacy, Arabic slave narratives have not garnered the same attention and interest in the field of literary studies. Safet Dabovic investigates this absence when he states in his dissertation, "Displacement and the Negotiation of an American Identity in African Muslim Slave Narratives," that "Muslims produced innovative slave narratives that made fascinating contributions to the formation of black cultural identity in the United States" (59). Dabovic speaks not only to the lack of inclusivity in American culture but by extension to the lack of inclusivity in the scholarship on African Muslim slave narratives. In fact, Florence Marfo presents some reasons why this may be in her article "African Muslims in African American Literature" by stating that there, "are some tentative grounds for including early narratives by Muslims within broader discussion of early narratives by non-Muslim slaves and the slave narrative genre" (1220). This hesitation comes down to the fact that they were not generational slaves like Frederick Douglass, who was born into slavery; therefore, their narratives do not fall under the American slave narrative genre. Paul Lovejoy reinforces this idea when he suggests that narratives written by African born slaves 
should be named "freedom narratives" because they once were free. While Lovejoy's idea may highlight the unique character of these narratives, I argue against this claim because African Muslim slave narratives are more similar to the traditional slave narrative than is generally thought. Despite the language difference and despite who writes the narratives, they still write about their condition in American slavery. Furthermore, these slave narratives are about the power of literacy. We should focus on what these narratives did for the future of the slave narrative genre and not separate them because of the language in which they were composed.

In regard to what Arabic and English slave narratives have in common, Frederick Douglass's path to freedom was lauded by white abolitionists just like the Arabic literate slaves before him. Both gained prominence and distinction whether through their self-made literacy and oratory skills or through the allure of Arabic for white patrons. Although there is a century between Douglass and the men I will be discussing, it is clear that literacy, especially in the language of the slave master, was a threat to the institution of slavery. Arabic literacy, however, not only exoticized and distinguished these men, but it also introduced a different threat, one in a language unknown to the oppressor. 


\section{Chapter 1:}

\section{Literacy, Muslims in early America, and the Role of America's Presidents}

Arabic literacy amongst African slaves not only represented a threat to whites

intellectually, but it was also at the center of rebellions around the world. The most well-known Muslim led rebellion took place in Bahia, Brazil in 1835, but before this revolt took place, African Muslims gathered together and carefully planned it by utilizing their Arabic literacy. The reason for their revolt in 1835 stemmed not only from the fact that they were enslaved, but that they were unable to practice their religion openly. Only after this revolt did the Christians of Bahia discover that the Muslims were operating Qur'anic schools where they taught children how to read and write Arabic. Through testimony, it was revealed that free and enslaved Muslim Africans were secretly teaching each other how to read and write. The Bahian police confiscated "dozens of wooden slates," and "papers written in Arabic" (Servants of Allah 119), which they believed was propaganda. However, after another slave translated the documents, he established that these were only alphabet lessons, and another document was a writing lesson. Sylviane Diouf writes that the thirty documents seized by the police show

the array of Islamic writings done by Africans, enslaved and freed. Some were written in perfect calligraphy and grammar and testify to the high level of knowledge attained by Muslim intelligentsia before its deportation to Brazil. Other papers were apparently written by beginners: they copied, time and again, passages from the Koran as a way of memorizing them and exercising writing skills. (119)

The Bahian government's suppression of religious freedom amongst slaves seems to have stemmed from their fear that Islam would spread in the country. However, the Qur'anic excerpts 
they found after the revolt were surahs 105 through 114, which were known to deal with trust in God and the fact that cruelty and the act of persecution would eventually turn against the oppressor. Using these surahs as evidence, the enslaved Muslims seemed to be fighting against the institution of slavery and their right to practice their religion without fear of retaliation. In fact, there is no evidence to support fears that they intended to spread Islam throughout the region.

The theory that they revolted for their political and religious freedom is supported by another historical rebellion that took place in Hispaniola on Christopher Columbus's son's sugar plantation in 1522. Known as the first African led rebellion in the Americas, Wolof Muslims "went from plantation to plantation trying to rally other Africans" because "they could not accept being enslaved by Christians or forced to convert. Their complete refusal of their new situation translated into disobedience and rebellions" (Servants of Allah 146). Although Diouf does not investigate whether Arabic played a role in the events leading up to the rebellion, they would have had to develop some way of retaining their identities through secret writing practices, which African Muslims in Bahia would exercise many years later.

The presence of African Muslims and their Arabic narratives suggests that Islam was not a recent addition to North America. Edward Curtis writes in Muslims in America: A Short History that slaves like Ayyub Bin Suleiman, or Job Ben Solomon as his patrons referred to him, contradict the claim that Muslims have not been a part of American history for generations, "Job arrived more than three decades before the United States declared its independence from Great Britain. Though historians still debate exactly how many African Americans in North America were practicing Muslims — estimates range wildly from the thousands to more than a million_-" (4). According to Allan D. Austin's article "Contemporary Contexts for Omar's Life and Life," 
approximately 29,695 African Muslims were taken to the United States during the Antebellum period (135). Michael Gomez writes in "Muslims in Early America" that they "may have come to America by the thousands, if not tens of thousands" (103). Sylviane Diouf estimates in Servants of Allah that about twenty-four percent of enslaved Africans who were brought to the thirteen colonies and later the United States were from Senegambia, a region between Senegal and Gambia rivers. This region, as Diouf remarks, "had, potentially, the highest proportion of Muslims" (Servants of Allah 48). It is hard to refute African Muslims' historical ties to the United States. In fact, African Muslim slaves' presence as well as Islam's goes beyond the plantation directly to the White House.

Thomas Jefferson is embedded in this complicated relationship between America and Islam. It first began with a discovery that he purchased an English translated Qur'an when he was a law student at the College of William and Mary. As Jeffrey Einboden writes Jefferson's possession of an English translated Qur'an sparked "commentary and criticism" (Jefferson's Muslim Fugitives 7) and later, questions of authenticity regarding the matter of his possession of two Arabic manuscripts written by African Muslim slaves during his time as president. The matter of authenticity begins with the question of how these two manuscripts were seemingly hidden for more than two centuries. Einboden believes that the reason this story of two Arabic manuscripts went unnoticed for so long was because it seemed implausible; he writes, "The idea of Thomas Jefferson receiving Arabic writings by enslaved Muslims in America sounds close to incredible. The conditions and coincidences necessary for such a story seem difficult to accept" (Jefferson's Muslim Fugitives 7). This difficulty seems to stem from the distance between when they first arrived in Jefferson's possession and when they were actually discovered. Many of Jefferson's colleagues and friends were coming into possession of their own Arabic manuscripts 
that were also written by Muslim slaves (Jefferson's Muslim Fugitives 9); so, it should not have come as a surprise that he too came to them. Einboden argues that since the presence of Muslim slaves in early America was virtually unknown, perhaps Jefferson was unaware of their existence as well. To support this argument, he references Denise Spellberg's Thomas Jefferson's Qur'an, writing, "Spellberg helpfully highlights the presence of Muslim slaves in early America, but also assumes Jefferson's own ignorance of the fact" (9). This theory does not seem to align with the fact that Jefferson's own friends were collecting Arabic slave writings, and it would be around this same time that a mysterious man would also approach Jefferson.

On October 3, 1807 Jefferson received a strange note from a man named Ira P. Nash, asking for a meeting with the president to discuss something of great importance. After meeting with him on October 4, 1807, Nash left two pieces of Arabic writing in Jefferson's possession. The Arabic writing belonged to two runaway slaves in Kentucky who, unable to communicate with their captors, resorted to writing in the only language they knew. Although the Arabic in this manuscript is filled with errors and omissions, some words are clear with Einboden speculating that it is the chapter from the Qur'an titled Al-Adiyat which means "The Runners." He writes, "the Arabic words written by men on the run reflected their Muslim faith, but also seemed to mirror hopes of flight" (Jefferson's Muslim Fugitives 134). While Einboden's interpretation is intriguing, I believe this manuscript includes the title of the second chapter from the Qur'an, Surah Al-Baqarah, which means "The Cow." Throughout my research, I have been able to decipher the different ways the Arabic has been written by Muslim slaves: the first is a distinct difference in letters from the way traditional Arabic is written. Below, the red line indicates what I believe is the actual chapter to which this slave refers. Although there are many errors in the writing, I believe the intended word was البوة, which is the Arabic writing of Surah 
Al-Baqarah, but the word is broken up into two lines, making it even more difficult to come to that conclusion. Another indicator that this manuscript includes references to the second chapter from the Qur'an is the inclusion of a fragment from verse 214 which asks the question, "When will Allah's (God's) help come?" I have also noticed throughout my analyses that the letter ف, pronounced like the English letter 'f,' in the slave narratives I will be discussing is pronounced as ق, which is a more emphasized English pronounced 'q.'

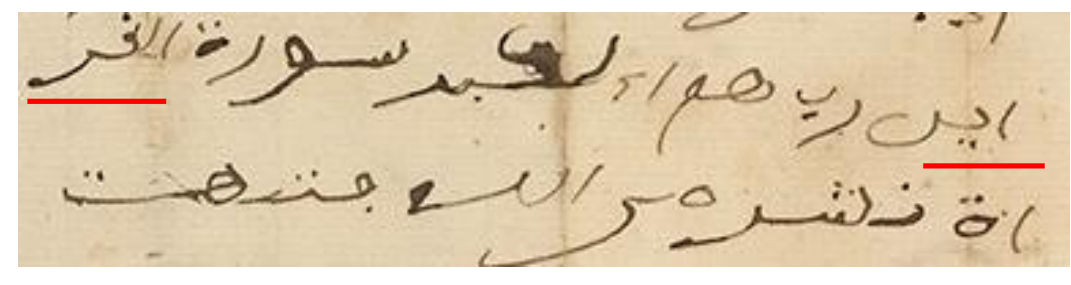

Although Einboden attempts to identify the chapter that is alluded to, he believes it is actually verse thirteen from chapter sixty-one. I, however, believe it to be verse 214 from chapter two of the Qur'an because the context of the verse supports a theme that many slaves use: certain verses to speak to their current condition. Many verses from the Qur'an use similar words throughout that indicate the same meaning, so it is difficult to tell from where these fragmented verses come.

Despite Jefferson's inability to read Arabic, he was familiar with the language, having signed a treaty with Morocco that bore the same foreign characters twenty years earlier. Interestingly, Nash chose to reach out to Jefferson regarding the writings of these captured men because he believed Jefferson had proven throughout his career that he cared about literacy and freedom of speech. Although these men were runaways, their literacy would confound their captors and make them more suspicious of who they were and from where they came. For two weeks, Jefferson sought a translator for the mysterious writings, but found no one in the capital who spoke or understood Arabic. His next attempt was to reach out to a man named Robert 
Patterson, a professor of mathematics and an anti-slavery activist who also invented ciphers (Jefferson's Muslim Fugitives 155). Presumably, Jefferson believed that because he viewed these writings as enigmatic, Patterson might be able to decipher them. In a letter to Patterson he writes, "the inclosed letters from a mr Nash contains all I know of them [the 'two men']: but the writings in Arabic characters are supposed to contain their history, as stated by themselves" (155). Jefferson assumes that the captured slaves have written about themselves, assigning meaning to their writing. This dynamic of assuming the contents of Arabic writings is common in many of the writings I will discuss in this thesis. But, why Jefferson assumes these to be autobiographical and what he hoped to find out from these writings is unknown.

All that can be made of Jefferson's connection to these Arabic writings is that he made every attempt to find out what meaning they held and intended to help these men gain their freedom (Jefferson's Muslim Fugitives 181). The idea that Jefferson wanted to aid them in attaining their freedom seems to contradict many of Jefferson's positions over the course of his life. Einboden writes,

For the whole of his career, Jefferson argued in the abstract against slavery, even as he continued to profit from the "peculiar institution" personally. Challenging enslavement via universal ideals, Jefferson abided by America's status quo in specifics. During his many decades as a slaveholder, Jefferson rarely intervened to promote the freedom of particular enslaved persons; he released very few of those in his own charge, and even urged his own neighbors not to liberate their slaves when they were eager to do so. (Jefferson's Muslim Fugitives 157)

Although Jefferson's ideals seem contradictory, he makes an exception in this unique case. Perhaps the fact that they were literate intrigued him or perhaps the Declaration of Independence 
he authored in 1776 rang in the back of his mind, guaranteeing the right to practice any religion freely and may have prompted him to act. Either way, Jefferson reached out to friends and acquaintances that he thought were familiar with Arabic, but none of them had an intensive understanding of the language and could not help in his quest. Over time, Nash updated Jefferson on the matter of the two slaves and wrote to tell him the men were forced to "labour daily" (Jefferson's Muslim Fugitives 184), and, not waiting for outside aid, saw this is an opportunity to escape. The men headed eastward but would, unfortunately, be captured once more, this time in Tennessee. However, they persisted and again escaped, but that would be short lived. They were once again imprisoned in Tennessee. On January 6, 1808 Jefferson read his final letter from Nash, "Those men whose Situation I mentioned to you have made their escape whither they are there at this moment I am not able to inform myself for I am so far past that place that no person can give me particular information of them-Tis observed that those travellers infallibly steer Eastward when at Liberty" (Jefferson's Muslim Fugitives 190). Presumably, Nash wrote this letter the first time the men escaped as he was only able to acquire new information about their condition while he was on his way home to Mississippi. Thus, Jefferson's hope of translating the Arabic manuscripts was put to an end.

Although this story of Jefferson's connection with Muslim slaves has long been buried, John Adams faced a similar situation twenty years later. His administration worked to help Abdul Rahman Ibrahima attain his freedom. After securing his own freedom, Abdul Rahman tried to free the rest of his family and was invited to the White House to meet President Adams in 1828. On meeting Abdul Rahman, Adams writes in his diary, "Abdul Rahaman the emancipated moor brought me a subscription book to raise a fund for purchasing the freedom of his five sons and his eight grand-children, to which I declined subscribing" (Jefferson's Muslim 
Fugitives 228). Despite both President's close proximity to Muslim slaves, their interactions are incredibly limited by their unwillingness to offer more assistance. Jefferson's and Adams's interests and concern revolved around literacy or its peculiarity in an American society, and even though Jefferson writes that he wanted to help the two Kentucky runaways obtain their freedom, none of his actions point to his actively taking matters into his own hands. It is not clear why John Adams refused to contribute to Abdul Rahman's subscription, but Abdul Rahman successfully leveraged his Arabic literacy when he first sought his freedom. 


\section{Chapter 2:}

\section{Reading the Lives of Muslim Slaves and their Arabic Writings}

This chapter of my research introduces three important Muslim figures in American slavery. These sections include short biographies, the circumstances that brought about their enslavement, their lives during enslavement, and a close analysis of their Arabic writing. My contribution in examining their Arabic writing serves a dual purpose. The first is to establish how they used their literacy to their advantage and how they challenged early American stereotypes that Africans were too inferior to acquire a rigorous education—or an education at all. The second is to determine their level of literacy and how that would be a determining factor in their eventual Orientalizing. I begin with Ayyub bin Suleiman or Job Ben Solomon, whose time in North America was short lived but would make a lasting impression in England. In my discussion of Ayyub, it will become evident that of the three he largely escapes the process of deAfricanization. However, as Abdul Rahman is introduced, Arabization of his identity begins and continues throughout his interaction with his white patrons. Finally, I will discuss the life of Omar ibn Said whose Arabic writing can be analyzed from multiple points of view. 


\section{Ayyub bin Suleiman (1701-1773)}

The life of Ayyub Bin Suleiman is quite different from the lives of the men who came after him. Throughout time, his narrative has attracted the most attention for various reasons. Before exploring these reasons and the events that took place during his enslavement, it's important to discuss his background and what led to his enslavement. Like Omar ibn Said and Abdul Rahman Ibrahima, Ayyub was raised in West Africa, specifically in Bundu, present day Senegal. According to Munawar Ali Karim, Ayyub's surname, "Diallo," which means "bold," indicates that he came from an influential family and that, "most of Ayyub's family members seem to have been Imams [a person who leads prayer in a mosque], teachers and scholars" (Liberty's Jihad 114). In fact, he finished his education and became an Imam at the age of fifteen. His education shared some but not all characteristics with that of Omar and Abdul Rahman, "As an Imam he had benefited from a religious training which would have earned him a reputation for a competency in Arabic, memorization of the Qur'an, leadership, piety, and devotion to worship and the quest for knowledge" (Liberty's Jihad 116). Although Omar was well educated in Arabic, being able to both write Qur'anic verses and conversational Arabic, he was not an Imam. He also was not able to write the Qur'an in its entirety, something that Ayyub did, not once, but three times while he was in England awaiting manumission.

Ironically, Ayyub was captured into slavery while he himself was selling enemy Malinke captives as slaves. In 1730, Ayyub's father sent him on a two-hundred-mile journey to sell the slaves and to also purchase paper, which was a "cherished commodity for West African scholars" (Liberty's Jihad 117). When he reached the Arabella, an English merchant ship, he argued with the captain, Mr. Pike, and eventually sold the slaves elsewhere. After doing so, he and his friend who accompanied him took a break before continuing their journey. Letting their 
guard down and hanging up their weapons, they were ambushed by enemy Malinke and taken prisoner. The Malinke shaved their new captives' heads and beards to pass them off as slaves taken in war. Incredibly, they were led to the same ship, the Arabella, and the same captain deemed Ayyub and his friend in good enough condition to purchase. Ayyub pleaded with Captain Pike, reminding him that he had been there earlier with slaves to sell and even offered two slaves for himself and his friend if he would free them. Pike agreed to this deal, allowing four days for a messenger to reach Bundu. Unfortunately, the trip to Bundu took a week, and on March 1, 1730, the ship set sail with Ayyub as part of the cargo. It is unclear when Ayyub arrived in America, but he found himself in the Annapolis slave market where a tobacco farmer named Mr. Tolsey who resided in Kent Island, Chesapeake Bay bought him.

Not much is known about Ayyub's relationship with Mr. Tolsey, but it seems that he put Ayyub straight to work. Ayyub, not used to the demands of labor on a plantation, eventually grew weak and was allowed to do easier work. His new position was to mind Mr. Tolsey's cattle, something he did when he lived in Bundu. During this time, in an unfamiliar place with no understanding or grasp of English, he would retreat into the woods and perform the obligatory Muslim prayers. However, a young white boy who frequently watched him, began teasing him. This would be too much for Ayyub, who decided to flee, travelling roughly forty miles until he arrived in modern day Kent County, Delaware. In June of 1731, Ayyub was captured and kept in jail until his owner came to claim him. While he waited, Thomas Bluett, who would become one of Ayyub's most influential friends and advocates, heard of a strange slave who did not speak English and who "prayed in a strange fashion" (Liberty's Jihad 125). He writes of Ayyub, “Upon our talking and making signs with him, he wrote a line or two before us, and when he read it, pronounced the words Allah and Mahommed; by which, and his refusing a glass of wine we 
offered him, we perceived he was a Mahometan...we could perceive he was no common slave" (125). It is interesting that like Omar and Abdul Rahman, Ayyub's distinction began with his escape and his display of Arabic writing. It is in prison or, in the case of Abdul Rahman, in the act of fleeing, that their uniqueness amongst other slaves is emphasized. According to Thomas Bluett, Ayyub maintains his Muslim identity through praying regularly and abstaining from drinking the alcohol offered him; Bluett later writes more about Ayyub's dedicated practices in maintaining this identity.

After a translator was called in to communicate between Ayyub and the jailers, they wrote a letter to Mr. Tolsey informing them of Ayyub's capture. After bringing Ayyub back to the plantation, Mr. Tolsey was "much kinder to him than before; allowing him a place to pray in, and some other conveniences, in order to make his slavery as easy as possible" (Liberty's Jihad 125). Why Mr. Tolsey agreed to make these accommodations is unknown, but after discovering Ayyub's uniqueness as a slave, he was willing to make changes to his living conditions. This also draws a stark difference between the owners of Abdul Rahman and Omar, who tried to manipulate them into converting to Christianity. In Abdul Rahman's case, his patrons hoped he would act as a Christian missionary and spread Christianity once he returned to Africa, but there is no record of him acting as a missionary. It seems Ayyub avoids this compulsion and earns the respect of those around him, so much so that he is given access to paper and ink. Below is the first page of the letter Ayyub addressed to his father in 1731, describing what befell him. He sent the letter with the same man who sold him into slavery, Mr. Denton; this letter was then passed onto Mr. Hunt, the merchant who employed Arabella's captain, Captain Pike. Mr. Hunt could not pass the letter to Mr. Pike, as he left London before its arrival, but he kept it in case another opportunity arose. 


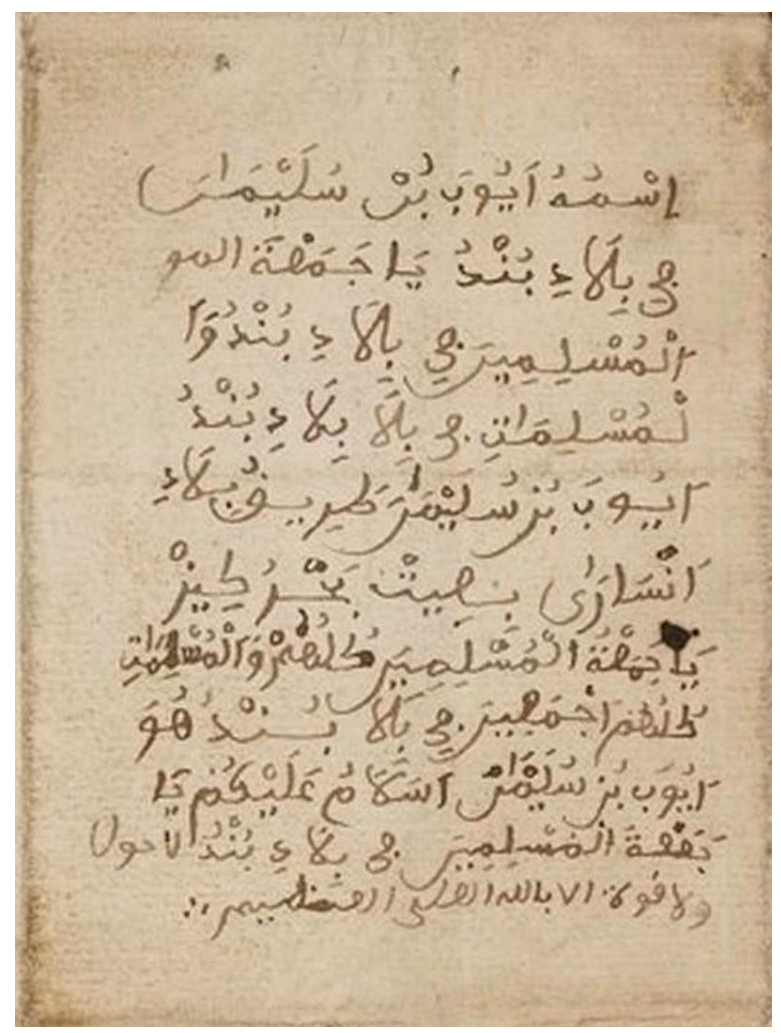

While the letter was in his possession, he showed his friend, James Oglethorpe, then the director of the Royal African Company, an English mercantile company whose interest compelled his original seller, Mr. Denton, to buy him back. In June of 1732, Ayyub was released, but not freed from slavery. Several months would pass, but in March of 1733 Ayyub set sail for England with Thomas Bluett where he was taught some English on board. Bluett writes that, "in about a fort-night's time [I] taught him all the letters, and to spell almost any single syllable, when distinctly pronounced to him; but Job and myself falling sick, we were hindered from making any greater progress at that time" (Liberty's Jihad 129). Ayyub's sea sickness did not stop him from gaining the favor of the sailors and other officers on the ship, nor did it stop him from carefully writing down what he observed of the lands on their voyage. Despite his ability to hold complex conversations about religion, and his overall manner and wit, Ayyub was still not completely free. Bluett writes that Ayyub felt as though he were just being passed from 
owner to owner, his freedom slowly slipping out of view. In the meantime, Ayyub's circle of friends grew, and it seems that his identity as a Muslim and a scholar was the reason for his popularity. Most admirable was his observance of Ramadan during his time in England. Ayyub would have been exempt from fasting while travelling according to Islamic law, but he felt free enough to practice it. Thomas Bluett's writing about Ayyub, although composed many years before Jefferson's Notes on the State of Virginia, is perhaps the first published piece about an African slave to challenge ideas about their intellectual and social capabilities. He writes of Ayyub:

On all occasions he discovered a solid judgement, a ready memory, and a clear head. And, notwithstanding the prejudices which it was natural for him to have in favour of his own religious principles, it was very observable with how much temper and impartiality he would reason in conversation upon any question of that kind, while at the same time he would frame such replies, as were calculated at once to support his own opinion, and to oblige or please his opponent. (Liberty's Jihad 134)

Ayyub's ability to remain reasonably impartial was fully displayed when he was given an Arabic copy of the New Testament where he told his friends that he read it carefully. He tells Thomas Bluett that "he told me he had perused it with a great deal of care, but could not find one word in it of three Gods..." (136). Ayyub is of course referring to the Holy Trinity. Like Omar, who had his own Arabic Bible, Ayyub recognized similarities between the Bible and the Qur'an.

Ayyub also impressed his new friends and patrons with his ability to write the Qur'an from memory. In fact, during his enslavement he would write three copies of the Qur'an, with Bluett stating, "His memory was extraordinary; for when he was fifteen years old he could say the whole Alcoran by heart, and while he was here in England he wrote three copies of it without 
assistance of any other copy, and without so much as looking to one of those three when he wrote the others" (Ali Karim 134). Below is the introductory page of Ayyub's handwritten Qur'an, copied in 1734 with his portrait on the opposite side. The second image is of Ayyub's writing of chapter five from the Qu'ran, Surah Al-Ma'eeda. In Ayyub's case, his writing of the Qur'an is not as unique as Abdul Rahman's and Omar's because he was able to openly profess his religion, while his counterparts had to use their knowledge of Arabic and the Qur'an to influence their circumstances. Although Ayyub has the entire Qur'an memorized by heart, he does not include tashkeel, which are phonetic guides used to inform the pronunciation of words. Tashkeel is only ever used in Qur'anic Arabic, which is displayed below in Ayyub's introductory page of his handwritten Qur'an. However, the image of Ayyub's actual Qur'anic writing is also noticeably free of these Arabic diacritics. The only phrase, underlined in red, includes the diacritics. On the one hand, it is most likely that Ayyub knows the pronunciation of each of the words because of his training and would therefore not need the tashkeel to guide his reading. On the other hand, he may have found it time consuming after writing the phrase, bismillah arRahman ar-Raheem. I have included a traditional writing of the phrase as a comparison to Ayyub's that shows Ayyub knows where the diacritics should be placed without aid from any other source.

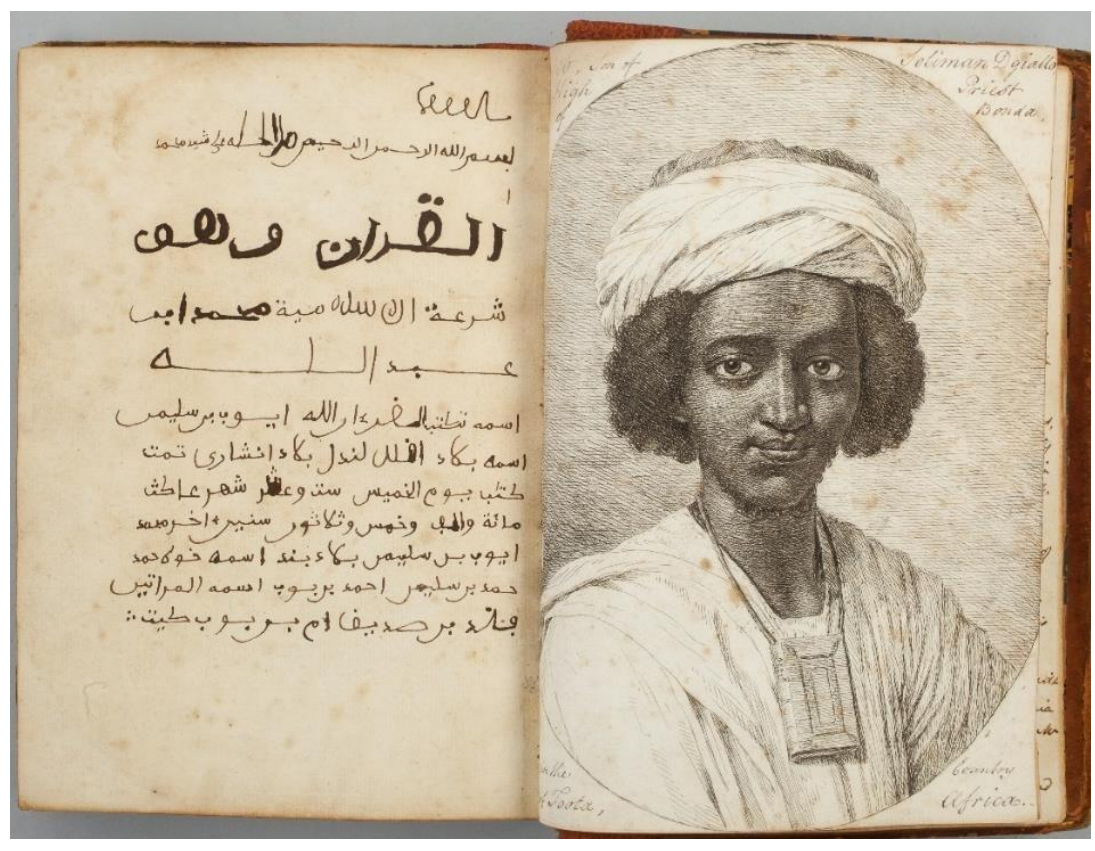




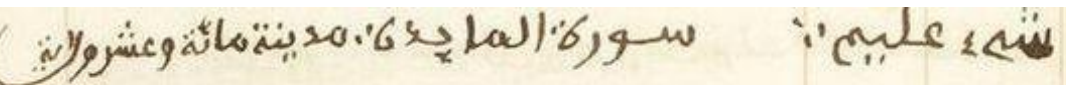

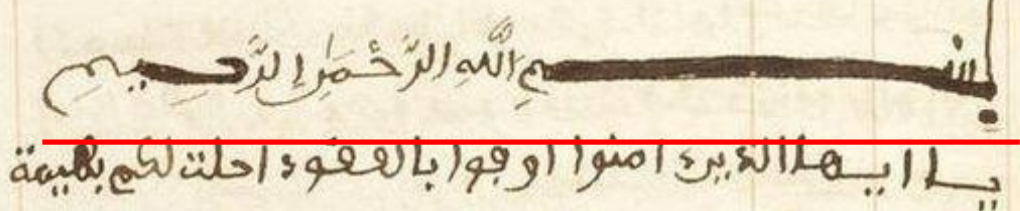

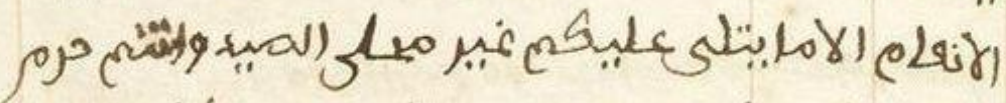

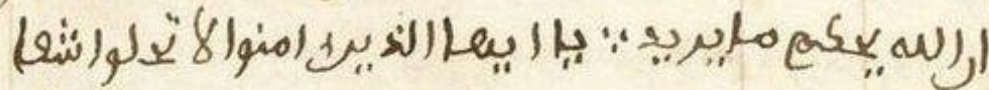

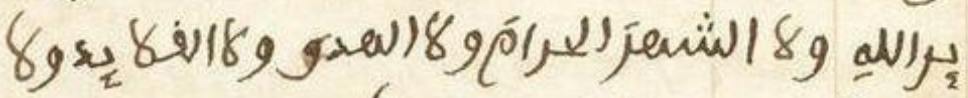

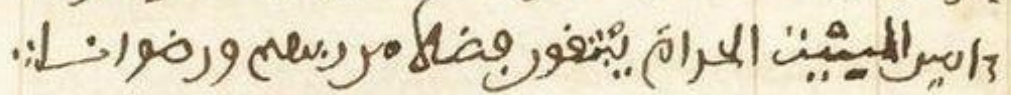

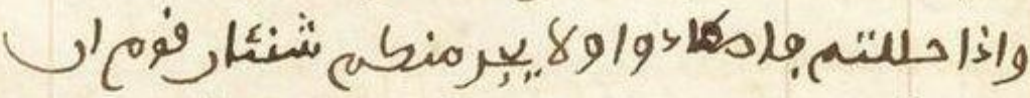

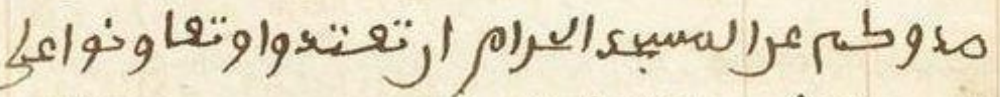

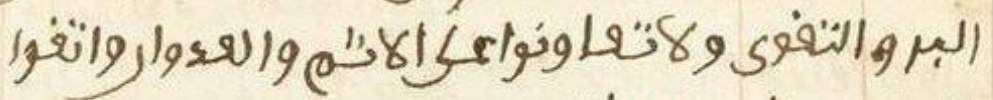

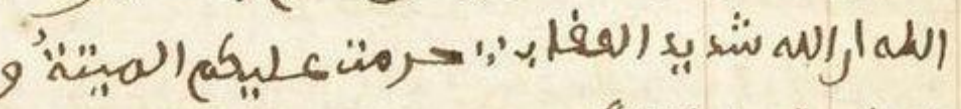

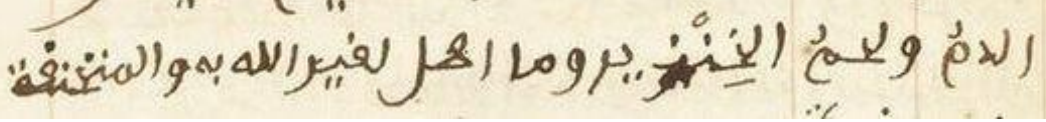

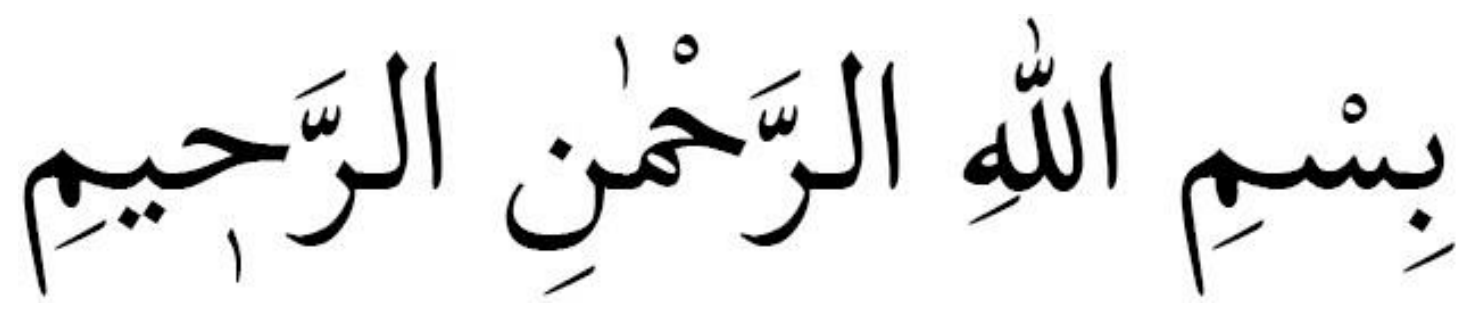

The Arabic style of writing used by Ayyub is the same style used by Abdul Rahman and Omar called "Meghrebi," which refers to a style of Arabic script developed in North Africa ${ }^{1}$ that would eventually spread to West Africa. Omar's and Abdul Rahman's patrons did not know what style of Arabic they wrote in, but it is significant that they only associated Arabic with the Northern part of Africa and would assume or claim these men were Moors and Arabs.

\footnotetext{
${ }^{1}$ Such as Morocco, Algeria, Tunisia, Libya, Egypt, and northern Sudan.
} 
For scholars like Douglas Grant, Ayyub's letter to his father was "the beginning of AfroAmerican literature" (Liberty's Jihad 126) and that it appears that he was fortunate to have escaped de-Africanization. Ayyub impressed his patrons and new friends so much that he was referred to as an "African gentleman" and gained such affluence among them that he was inducted into the Gentlemen's Society of Spalding² on June 6, 1734 (Liberty's Jihad 138), which welcomed members such as Alexander Pope and Sir Isaac Newton. He also met the Royal family and befriended the Duke of Montague. Unlike Abdul Rahman Ibrahima, who was dubbed the "Moorish Prince," and paraded across the country in Oriental attire by his patrons, Ayyub’s African identity was underscored, also by having his portrait painted by William Hoare. At first, Ayyub rejected having his portrait painted, but after being assured that his portrait would only be for them to remember his likeness, he agreed on the condition that he be able to wear clothes of his country.

Although a precise description of the clothing he wore in the portrait are not described, we know that Ayyub was gifted clothing "prepared in the Fulbe style, which Ayyub wore for his audience with the King and Queen" (Liberty's Jihad 138). Perhaps because Ayyub was the earliest known African Muslim slave in the Antebellum South he was able to distance himself from being called a Moor or an Arab. Or perhaps it was due to Ayyub's resistance to such assigned identities. Ayyub, unlike his counterparts, would escape Arabization, but it seems there may have been ulterior motives to his being welcomed into and respected in English society. Although most of Ayyub's life is carefully recorded during his time in England, there was a difference in the way Ayyub was welcomed in both societies. During his brief time in America,

\footnotetext{
2 "Founded in 1710, the Spalding Gentlemen's Society is Britain's oldest surviving provincial learned society" (sgsoc.org).
} 
he was viewed primarily as a body, made to work, while he views himself as an intellectual, humiliated by slavery. Ultimately, he is useless to the institution of slavery, and his former owner, Mr. Tolsey, deems him unfit for his business (Liberty's Jihad 128). In England, however, Ayyub is able to practice his religion; his intellect is recognized and appreciated, and he is not humiliated. This brings me to a second reason for Ayyub's persistent legacy, which was that the kind treatment Ayyub received was connected not to his potential for spreading Christianity, but to potential trade prospects in his homeland. Since Ayyub and his father were both prominent figures in their community and slave traders, Ronald Judy argues, his literacy paired with this fact, would only enhance:

his value as a commodity with growth potential; it did not buy his freedom. This is the point at which the story of Ayyub's exchange value gets fully under way. It was Ayyub's demonstrated capacity as source of information about the production and distribution network of gum arabica, as well as his potential as a trading partner in that important commodity, that fueled the Royal African Company's and subsequently the Crown's interest in him." (DisForming the American Canon 151)

Perhaps Ayyub did not know this, but gum was a European commodity, and Bundu's forests grew abundant supplies of gum trees. In fact, Thomas Bluett explicitly writes, "Considering the singular Obligations he is under to the English, [Job] may possibly, in good time, be of considerable service to us also; and that we have reason to hope this from the repeated Assurances we had from Job, that he would, upon all occasions, use his best Endeavours to promote the English Trade before any other" (Liberty's Jihad 142). The obligations Bluett writes about is the debt owed by Ayyub for the efforts made to secure his freedom, the cost of his travels to and around England, and the eventual payment of the subscription that would 
ultimately free him. However, there is no evidence to support the theory that Ayyub did succeed in helping establish trade relations between Bundu and England when he left at the end of July in 1734. However, many years later, another slave would be propositioned to further Western interests in Africa. 


\section{Abdul Rahman Ibrahima (1762-1829)}

One of the more prominent slaves to find themselves in the Antebellum South was Abdul Rahman Ibrahima, better known as the "Prince" amongst his fellow slaves, his owner, and his white patrons. His example illustrates the importance of learning and literacy, especially considering the community in which Abdul Rahman was raised. Abdul Rahman was born in 1762 in Timbo to Sori, king of a cattle-raising people, the Fulbe. His father was known as both a warrior and strong leader amongst his people, but eventually lost his title as "Almaami" (he who leads the community in prayer) after his people and army turned against him. Years later, he would be restored to that title, but not before proving himself once again as the fierce leader he was known to be. Out of Sori’s many sons, Abdul Rahman was his favored one; he took special care to ensure that Abdul Rahman had an education befitting the son of a king. Receiving such a prestigious education was not unusual amongst the higher classes in Abdul Rahman's community. Furthermore, the community paid "considerable attention. . . to the acquirement of knowledge" (Prince Among Slaves 6). Because Abdul Rahman was a Muslim, most of his education was rooted in the study of Islam. However, his education was not solely religious. Terry Alford writes in Prince Among Slaves that "schools associated with clerics at the mosques taught them reading, writing, arithmetic, and languages. Manuscript texts of the Quran, the Pentateuch, and other works were circulated" (6). Paper and books were common but prized gifts. While education was emphasized, the people of Futa were constantly at war with neighboring communities having fled to Timbo, a first rank political town that Abdul Rahman's father oversaw, to avoid clashes with the rival Solima community. Despite a long and bloody war, schools in Timbo remained open which spoke to "their [Muslims] love of learning" (Prince Among Slaves 11). 
Following a traditional model, Abdul Rahman's education was rooted in Islam, and he was required to attain a certain level of literacy in order for him to move beyond being a student, to becoming a teacher. Thus, his schooling began at age seven. His education was "traditional; first he learned to read, then to write, passages from the Qur'an. Community schools in Egypt and Morocco are taught the same way. These were the first lessons of young Muslims everywhere, learned by the rote and endless practice and forgotten only when memory itself is abandoned" (Prince Among Slaves 12). Although such an education was common for all of Abdul Rahman's peers, he practiced for long hours, and his father, seeing this interest, sent him to study abroad in Macina and Timbuktu when Abdul Rahman was twelve years old. Before being sent abroad, Abdul Rahman was already familiar with the Qur'an having been able to read it without error long before he continued his upper-level studies. Once abroad Abdul Rahman attended Qur'an classes along with geography, astronomy calculation, and Islamic and country law classes. On two separate occasions, two contemporary American biographers of Abdul Rahman who were also versed in eastern languages, Thomas H. Gallaudet and John Frederick Schroeder, wrote that Abdul Rahman was "well versed in Oriental literature" and that he was "very familiar with the Koran, many passages of which he read for me [Schroeder] with correctness and fluency" (Prince Among Slaves 14). Before Abdul Rahman arrived in America, he had already established himself as an educated and literate man amongst white travelers; the only difference was that he was a free man.

In January of 1788, at the age of twenty-six, Abdul Rahman led a small army to fight the Igbo who had destroyed some vessels on the coast. Though it seemed to be an easy victory, Abdul Rahman and his army were tricked into fighting on uneven turf by the Igbo. He and his men were surrounded. Abdul Rahman told everyone to run if they wished. While some fled, 
others encircled him. He sat on the ground concealing his weapons but was injured from a stray arrow. While he was prepared to fight alone, the Igbos decided to spare his life after they recognized his clothing of high rank. After being knocked unconscious, he awoke to find himself and almost his entire army imprisoned. The Igbo took them one hundred miles to be sold as prisoners of war to African Muslim merchants who would in turn sell them to Europeans. Abdul Rahman's attempts at ransoming himself were unsuccessful with Alford quoting an English slave trader as saying, "If they are captured that have been particularly active in wars — a King, Prince, or their sons-no price can purchase them” (Prince Among Slaves 23). Thus, Abdul Rahman was doomed to be sent as a slave to the Antebellum South. From Prince to Slave, Abdul Rahman would find himself in a strange place in a life unlike his own, treated not as a warrior but as a lowly servant. Soon, however, everyone would know who he was.

On August 18, 1788, after traveling six thousand miles to Natchez, Mississippi, Abdul Rahman was sold to Thomas Foster. Just as he had tried to ransom himself before boarding the slave ship Africa, he attempted to do the same with his new master. Despite Abdul Rahman explaining that his father would pay a large amount of gold for his return, Thomas Foster refused and decided to calling Abdul Rahman "Prince". While describing his sale, Alford pauses to juxtapose Abdul Rahman and the Fulbe to the men at the auction. He writes, "They were admired for their intelligence" (Prince Among Slaves 42) while of the prospective buyers he writes:

Thomas Foster joined a group of four men who pressed forward on Ibrahima and the others. These prospective buyers were an inauspicious bunch. One of them, Jeptha Hidgon, could not write his own name. Another, the equally illiterate George McKnight, was a dirt farmer who 
had never owned a slave before. The third, William Calvit, was an inebriate so penurious and cruel he would not give clothes to his own wife. Calvit's father, Frederick, was also present. (Prince Among Slaves 42)

As this description ironically illustrates, these slaves outranked their owners and overseers in terms of education and class status. Part of Fulbe Muslim tradition includes an emphasis on education, which Alford makes clear was not highly prioritized by the men around Thomas Foster. This comparison places Abdul Rahman beyond not only his fellow slaves but the very slave owners themselves. In fact, his comparison of the Fulbe and the buyers echoes what Sylviane Diouf writes in Servants of Allah, "the Muslims' literacy was dangerous because it represented a threat to the whites' intellectual domination and a refutation of the widely held belief that Africans were inherently inferior and incapable of intellectual pursuits" (108). Therefore, Abdul Rahman, as an intellectual, fits the title of "Prince" because of how literacy elevated him above even the white owners around him.

Although Abdul Rahman attempted to ransom himself by using his title (and by alluding to the money his father could pay), he was soon put to work with the other slaves. Nevertheless his identity as a Muslim may have helped to secure more freedom for him than for other slaves. Naturally, he was maddened by the labor he was not used to doing himself and resorted to running away. After many weeks in the woods, Alford believes Abdul Rahman contemplated suicide. Suicide was a practice amongst Africans of all classes who found themselves captured. Abdul Rahman, however, returned to the Fosters. From then on, he worked dutifully, helping the Fosters produce sixteen thousand pounds of cotton that eventually eased the financial burden the Fosters had accumulated over the years. By 1794, Abdul Rahman married a Christian, an American-born slave named Isabella. The marriage produced three children and proved to be a 
good match as Isabella helped Abdul Rahman assimilate to American life. Despite being married to a Christian woman, Abdul Rahman held firmly onto his faith mostly due to Thomas Foster's admiration of the supposedly Muslim characteristics of honesty and self-discipline exhibited by Abdul Rahman. Many of the Muslim slaves in the Antebellum South had gained reputations of being "sober, self-disciplined, and generally honest" (Prince Among Slaves 56). Owners like Thomas Foster therefore benefited from having Muslims slaves.

Alford writes that despite his religious freedom, "Ibrahima's intellectual circumstances were undeniably restricted and severe" (57) and that the "exhaustion of the field did not encourage literary pursuits as the political and religious excitements at home had done. Furthermore, Ibrahima had no access to pen and paper. He had no Qur'an. Years became decades, and he did not see a single Islamic text or piece of Arabic writing. To retain his literacy he took to tracing Arabic characters in the sand when Thomas would call a rest during work" (57). Despite eventually living as a slave for the next forty years, Abdul Rahman would learn very little English and though his master's family was largely illiterate the "secret superiority that Ibrahim might have felt on this subject rang hollow in the rude atmosphere of the farm" (Prince Among Slaves 58). The secrecy of Abdul Rahman's superiority would soon end in 1807 with a remarkable reunion with Dr. Cox, an Irishman who had lived with Abdul Rahman and the Fulbe prior to his enslavement when Cox's ship had left him behind. During his years with the Fulbe, Cox and Abdul Rahman grew fond of each other with Cox eventually returning home and never forgetting the kindness bestowed upon him by Abdul Rahman and his people.

Cox tried his best to help liberate Abdul Rahman, offering upwards of one thousand dollars for him, but Thomas Foster refused. Still ignorant to the extent of Abdul Rahman's education, Foster argued that Abdul Rahman would be unhappy outside of the estate. He 
believed him to be without skill and means of livelihood and Foster doubted that freedom in general would make him happy, a similar sentiment shared by Frederick Douglass's owners. Eventually, Cox would die without having succeeded in helping Abdul Rahman. While Dr. Cox was seeking to help Abdul Rahman obtain his freedom, Abdul Rahman met a man by the name of Andrew Marschalk. Marschalk, a former colonel turned runaway apprentice of a New York printer, brought the first printing press to Mississippi, and set up shop in Adams County in 1802. Abdul Rahman met him in 1803. In 1821, five years after Dr. Cox's death, Abdul Rahman was well acquainted enough with Marschalk to find himself visiting his printing office. While in his printing office, Abdul Rahman recognized a type foundry, which makes typefaces for printing presses, in Arabic and asked Marschalk if he could copy it. Marschalk writes that he copied it in "a very neat and handsome style, producing a facsimile; he also rendered it in English" (Prince Among Slaves 89). After copying, Abdul Rahman asked if he might be able to write home, inquiring whether Marschalk knew of any way to do so. Marschalk recommended his friend Thomas D. Anderson, then a United States consul in North Africa. Surprisingly, Abdul Rahman refrained from writing the letter. Alford speculates about why he would suddenly change his mind and argues that Abdul Rahman feared he would be caught in a lie. Since Marschalk and others assumed him to be a Moor (from Morocco), and since he had no family there, a letter to Morocco would "embarrass and discredit him" (Prince Among Slaves 90).

However, in 1826 Abdul Rahman would finally write his letter to Morocco. No record was kept of what Abdul Rahman wrote, but it was an excerpt from the Qur'an, which was delivered to Thomas Mullowny, the consul in Morocco. Marschalk believed it would be enough to confirm Abdul Rahman's Moorish identity. The letter was then forwarded to the king of Morocco who acted quickly and stated that he would pay for his freedom despite no 
confirmation of Abdul Rahman actually being a Moroccan royal. Mullowny writes, "The intention of the letter [writer] appears to me to prove he is a Moor, as [the text] is taken from the Qur'an to excite an exertion for his relief. The documents appear to be clear of deception" (Prince Among Slaves 100). With this breakthrough, Abdul Rahman at the age of sixty-five would finally be liberated with Thomas Foster agreeing to free Abdul Rahman under the condition that he enjoy his freedom in Africa and not the United States. Foster claimed that he was more than willing now to accept any offer of returning Abdul Rahman to his home and without cost. But, during the process of planning Abdul Rahman's liberation and return home, it was discovered that he was not from Morocco after all. Marschalk then suggested that they must inform the President of the United States, John Quincy Adams, of the mistake. However, Marschalk's letter to Adams omitted any mention of Morocco. This was an important choice made by Marschalk in Abdul Rahman's quest to attain freedom; it signifies a rejection of his true identity despite evidence refuting Moorish heritage. Adams's administration still maintained a special interest in Abdul Rahman's situation with the Secretary of State, Henry Clay, writing back to Marschalk, "The President is obliged by your attention to the subject of the Moorish slave...I have, therefore, to request that you will complete the humane agency which you have so kindly undertaken, by calling upon Mr. Foster, assuring him the above conditions shall be complied with, and receiving the custody of Prince from him" (Prince Among Slaves 107).

The choice to not mention the error of assuming Abdul Rahman was a Moor would later develop into an orchestrated performance of his Moorish identity. Thomas Foster and Abdul Rahman rode into Natchez on February 22, 1828 to meet Andrew Marschalk and to give him a deed in trust for Abdul Rahman. Before Abdul Rahman's liberation, he had expressed his desire to free his wife and children. This would only be possible if Abdul Rahman earned the funds 
himself. Marschalk, despite knowing the truth of Abdul Rahman's identity, paid for a "specially designed 'Moorish' costume for the Prince-including, in true Arabian Nights fashion, a turban with a crescent and star" (Prince Among Slaves 166). Terry Alford adds that he was also given "white pantaloons gathered at the ankles, and yellow boots. Even a scimitar was added to the outfit" to which Cyrus Griffin, one of Abdul Rahman's earlier patrons, objected to this "tawdry dress" (Prince Among Slaves 111). This attention to his alleged Moorish identity did not go unnoticed by Abdul Rahman. He played into his own de-Fulbing knowing that it would help him. In fact, it garnered him enough sympathy that within twenty-four hours of expressing his desire to free his wife, patrons across the country raised the funds to do so.

Marschalk knew Abdul Rahman's ability to help his family would be hindered if he did not play his part in the claiming of Abdul Rahman's Moorish ancestry. This performance arguably Orientalizes Abdul Rahman. As Edward Said writes, "it inevitably retreated into equating the Orient with private fantasy, even if that fantasy was of a very high order indeed, aesthetically speaking. In both cases, of course, Orientalism enjoyed a powerful influence on how the Orient was described and characterized" (Orientalism 176). Here, Abdul Rahman indulges Marschalk's views of how a Moor would dress, he takes on the role of the Arab, not the African. His Arabic writing would be treated similarly, making it hard for white patrons to rationalize an educated African in their midst. In fact, Munawar Ali Kareem reinforces this claim that African Muslims' literacy was a threat, writing, "the slave masters and American public in general felt at a loss to reconcile their backgrounds with the usual nonsense about 'black savages' being salvaged by the institution of slavery..." Furthermore:

Since these Muslim slaves—like 'Abd al-Rahman—were living evidence against the supposed backwardness of the 'Negro race' they had been portrayed as 
somehow different to their countrymen. 'Abd al-Rahman, with his Arabic name and royal background, was portrayed as a Moorish prince, and his education was therefore explained away as an 'Arab' education, not an 'African' one. Like most Muslim slaves 'Abd al-Rahman was exposed to the phenomenon of 'deAfricanisation', and to some extent played along with it entirely. (Liberty's Jihad 152)

It is only after Abdul Rahman is revealed to be a literate and well-educated man that his identity, which had already suffered a major blow during his captivity, is fundamentally altered.

Although he had been a slave for forty years, Abdul Rahman's mind was sharp enough to remember how to write some Arabic. The most widely circulated Arabic piece was Surat AlFatiha, or the first chapter of the Qur'an. Abdul Rahman's success amongst his white patrons was due in part to their belief that he would return home and spread the Christian word. They believed that what Abdul Rahman was writing was "The Lord's Prayer" in Arabic. In a sense, it could very well be "The Lord's Prayer" for Surah Al-Fatiha describes the most important qualities of God and a servant's oath to worship Him alone while staying on the straight path. Abdul Rahman's forty years as a slave undoubtedly created a spiritual and religious void in his heart that would eventually be filled by attending church services with Thomas Foster and his family. Terry Alford writes that Abdul Rahman saw these weekly visits as an "opportunity to escape the routine, and he must have enjoyed the social aspects of the day" (Prince Among Slaves 79). This opportunity to escape life on the plantation is an interesting theory; however Abdul Rahman's extensive Qur'anic education and knowledge offered him a connection that was otherwise lost. He was already familiar with key people and events in the Bible, as they are also mentioned in the Qur'an, and would use this familiarity to his advantage. 
Through his time with Foster Abdul Rahman was exposed to various sections from the Old Testament, in particular "The Lord's Prayer" which played a role in his gaining favor from his white patrons. While he traveled to raise the funds to free his family Abdul Rahman would, at the request of his patrons, write "The Lord's Prayer" for them in Arabic. Abdul Rahman, however, would actually be writing the opening chapter of the Qur'an, Al-Fatiha, or as it literally translates, “The Opener". Below is Abdul Rahman's handwritten version of this chapter, written on December 29, 1828. It is worth noting that even after forty years and meager opportunities to practice his Arabic through sand writing, Abdul Rahman was able to retain these seven verses with very few grammatical errors.

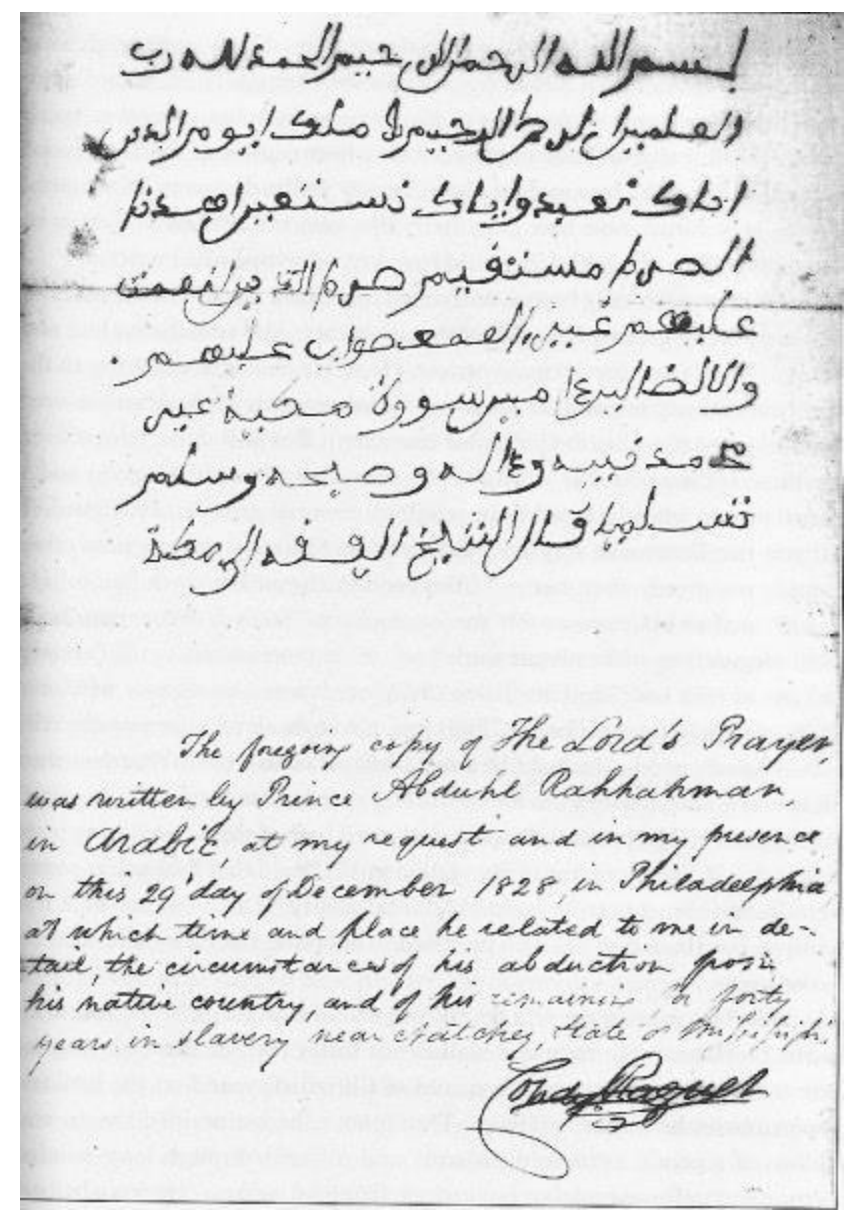

Transliteration of Abdul Rahman's version of Al-Fatiha:

1. Bismillah ar-Rahman, ar-Raheem

2. Al-hamdu lilahi Rab al-alameen

3. Ar-Rahman, ar-Raheem

4. Malikee yawm ad-deen

5. Eyaka na'budu, wa eyaka nesta'een

6. Ihdina as-sirat mustaqeem

7. Sirat Al-latheena an'amta alayhim ghayr al-mam'asoob alayhim wa lal-daleen Ameen 
The traditional and correct written version of Al-Fatiha: The traditional and correct transliteration of Al-Fatiha:
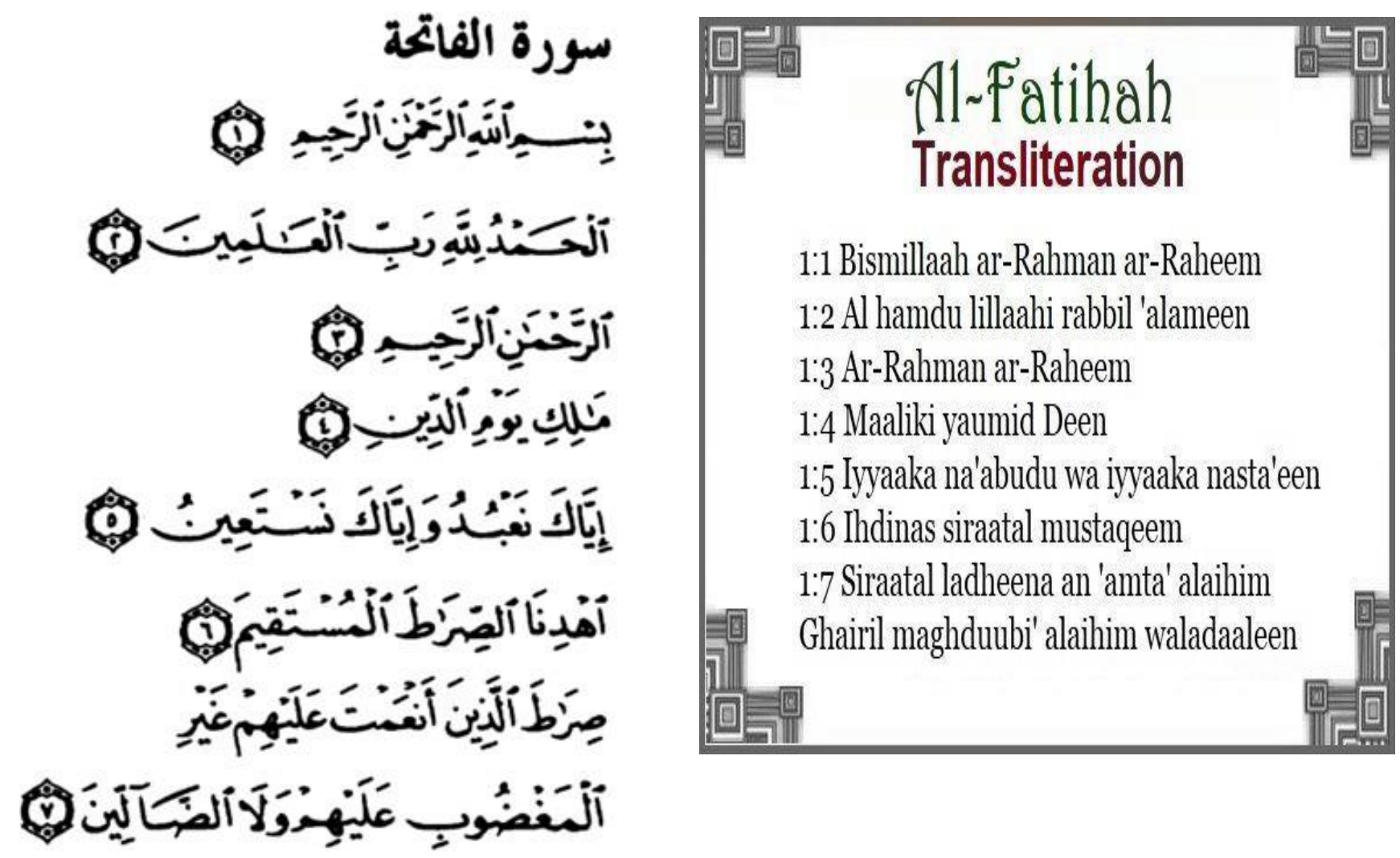

Abdul Rahman's using sand writing to preserve his literacy seems to have paid off forty years after his enslavement and proves that this small practice was instrumental in preserving his memory of the Arabic he grew up learning. The version that he wrote for his patron at times misses crucial alphabetical distinctions such as the placement of dots on certain letters, but the verses — for the most part—remain accurate. However, in the seventh verse, the word highlighted in red is written completely incorrectly. Abdul Rahman not only omits dots that belong to certain letters in the word, but he also repeats one of the letters right after he has already written it. Occasionally, misplacement of dots and repetition of letters change the meaning of the word but still produces a word that exists in Arabic. In this case, however, the word has no meaning and does not exist in Arabic. The reason for Abdul Rahman's error is hard to explain especially when 
the majority of his writing is legible and correct. The English written beneath Abdul Rahman's Arabic does not include "The Lord's Prayer" just that it is the prayer in Arabic.

His patron, Condy Raquet, writes below the Arabic writing that Abdul Rahman had written "The Lord's Prayer" at his request and that Abdul Rahman details his abduction and life in slavery. At this point, Abdul Rahman had made his way to Philadelphia, which his patron includes in his copy of the supposed Lord's Prayer. The question of why Abdul Rahman wrote Al-Fatiha as a substitute for "The Lord's Prayer" has a simple answer: they are very similar in meaning and would be the verse he would most likely remember. This chapter's seven verses begins with "In the Name of God, the Most Compassionate, Most Merciful" and goes on to describe God's position and dominion over all things including seeking Him for help, needs, and guidance. Al-Fatiha echoes the same sentiment, most particularly in the sixth and the seventh verse which mirror the tenth and eleventh line of "The Lord's Prayer".

In Al-Fatiha the verses are, "Guide us along the Straight Path" (verse 6), "the Path of those You have blessed — not those You are displeased with, or those who are astray" (verse 7). In "The Lord's Prayer" the text instead reads, "And lead us not into temptation (line 10), "but deliver us from evil" (line 11). The use of Al-Fatiha for Abdul Rahman may have been convenient as well because it may have been the only chapter of the Qur'an he remembered in its entirety. This opening chapter is known as "The Mother of the Book," because it is the most frequently recited part of the Qur'an. It opens every salah or physical act of worship performed by a Muslim and would be very hard to forget even after forty years. Interestingly, Abdul Rahman writes, "Meccan chapter revealed to Muhammad peace be upon him and his family," which likely refers back to his training as a youth. He would have learned where and when the chapter was revealed and felt the need to include it in the written version he gave this patron. 
Many of Abdul Rahman's patrons were motivated to help him due to their belief that he would convert and spread Christianity once he returned to Africa. Undoubtedly, Abdul Rahman would have seen this assumption as an opportunity to continue raising funds required to free his family, but historical evidence shows that Abdul Rahman never made any claim to convert or spread Christianity. In fact, Terry Alford writes that Abdul Rahman "learned to speak in halting phrases" (Prince Among Slaves 58) but was able to communicate and even went as far as criticizing Christians who did not practice Christianity as it should be practiced. Munawar Ali Karim writes that Abdul Rahman was quoted as saying, "the Testament very good law; you no follow it; you no pray often enough; you greedy after money" (Liberty's Jihad 168). This is evidence that Abdul Rahman would have been able to tell his patrons that he was indeed not writing "The Lord's Prayer" but that his patrons chose to believe that he did. Likewise, they also chose to believe he would carry out a Christian mission.

These beliefs owed to maneuvering on the part of his patrons with Cyrus Griffin hoping to make Abdul Rahman the "chief pioneer of civilization to the unenlightened" (Liberty's Jihad 156). They placed meaning onto Abdul Rahman's Arabic writing without consulting him and despite the similarities between the two texts, Al-Fatiha held more significant meaning to Abdul Rahman as it was a conversation between himself and the Creator and an assertion of his Muslim identity. As Ali Karim writes, "Abd al-Rahman was declaring his servitude, or slavery to Allah" and that he viewed the opportunity to travel from city to city as an "opening from Allah [God] to his benefit and the benefit of his family" and earned him $\$ 3400$ that went to remitting them (169). Abdul Rahman wrote Al-Fatiha many times during his travels throughout the country, and to him that was his "Lord's Prayer." Both "The Lord's Prayer" and Al-Fatiha asked of their reciters to practice reliance on God, and for Abdul Rahman it proved to be successful. 


\begin{tabular}{|c|c|}
\hline Traditional & Contemporary \\
\hline $\begin{array}{l}\text { Our Father, who art in heaven, } \\
\text { hallowed be thy Name, } \\
\text { thy kingdom come, } \\
\text { thy will be done, } \\
\text { on earth as it is in heaven. }\end{array}$ & $\begin{array}{l}\text { Our Father in heaven, } \\
\text { hallowed be your Name, } \\
\text { your kingdom come, } \\
\text { your will be done, } \\
\text { on earth as in heaven. }\end{array}$ \\
\hline Give us this day our daily bread. & Give us today our daily bread \\
\hline $\begin{array}{l}\text { And forgive us our trespasses, } \\
\text { as we forgive those } \\
\text { who trespass against us. }\end{array}$ & $\begin{array}{l}\text { Forgive us our sins } \\
\text { as we forgive those } \\
\text { who sin against us. }\end{array}$ \\
\hline $\begin{array}{l}\text { And lead us not into temptation, } \\
\text { but deliver us from evil. }\end{array}$ & $\begin{array}{l}\text { Save us from the time of trial, } \\
\text { and deliver us from evil. }\end{array}$ \\
\hline $\begin{array}{l}\text { For thine is the kingdom, } \\
\text { and the power, and the glory, } \\
\text { for ever and ever. Amen. }\end{array}$ & $\begin{array}{l}\text { For the kingdom, the power, } \\
\text { and the glory are yours, } \\
\text { now and for ever. Amen. }\end{array}$ \\
\hline
\end{tabular}

Like Abdul Rahman's writing of the opening chapter of the Qur'an, Al-Fatiha, his other piece of writing, written October 10, 1828, was also mistranslated. The opening line of this supposed autobiography begins similarly to an actual autobiography, which I have underlined in red, with Abdul Rahman writing, "My name is Abdul Rahman Ibrahima," but the English translation beneath the Arabic writing is not accurate. Just as his white patrons assigned meaning to his previous Arabic writing, they believed this was his autobiography written in Arabic, which would only be possible due to Abdul Rahman's frequent retelling of his life story to his white patrons. The translation of the rest of the Arabic refers to places like Mecca and Medina, which are two Muslim holy cities, and a sheikh, which is an honorary title given to a Muslim religious scholar. It concludes with the words, "Muhammad, son of Abdullah." There is no coherent connection between these fragments, but it is clear that Abdul Rahman is recalling any Arabic he can whether it makes sense or not. Although his second manuscript holds some religious significance, none of the lines are verses from the Qur'an. This is evidence of Abdul Rahman's limited knowledge of Arabic in general as his education prior to enslavement was strictly Islamic. It does not seem that Abdul Rahman's patrons knew that his Arabic was limited or that it would have made any difference in how they viewed him. His writing fascinated them to the point that they exoticized him and obliged him to play the role of an Arab. 


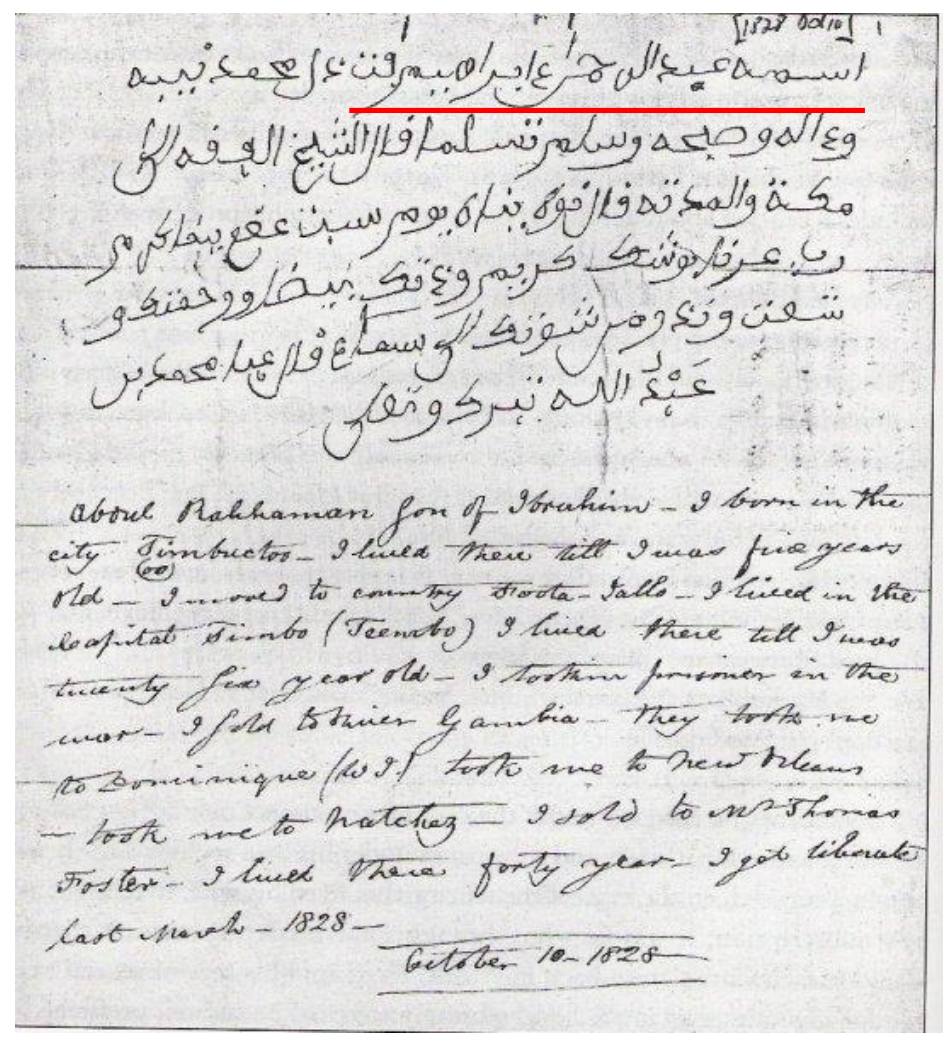

\section{Transliteration of Abdul Rahman's Supposed Biography:}

Line 1: Ismi Abdul Rahman Ibrahima bit ali Muhammad nayeeba

Line 2: wa alihi wa sahbihi wa salim tasleema, fala a-sheikh al wafa illa

Line 3: Mecca wal Madata, fal khuwa yawm sabt afa'a yanhakam

Line 4: rab arna wishak kareem wa'atakum yabkhalu rahmataku

Line 5: sha'at wa ta'ara min shawtak ila samaa fal abd Muhammad bin

Line 6: Abdullah tabarak wa ta'ala

The circumstances surrounding this piece of writing is purely speculation as Abdul Rahman may have been asked to write his biography in Arabic but wrote random Islamic sentences instead. However, he may have also voluntarily wrote this piece and said it was his 
biography. The first seems more likely as Abdul Rahman was asked to write "The Lord's Prayer" but produced the only accurate Arabic he knew from memory. He would not be able to produce the same Arabic for his biography as his patrons would notice the similarities and would disbelieve him being the Moorish prince they claimed he was. The reasons his patrons chose to believe that this text comprised his autobiography stems from their own ignorance of Arabic and their refusal to acknowledge Abdul Rahman's Africanness. The letter that would begin Abdul Rahman's journey from slave to prince may have contained Qur'anic verses as well, though it has not survived, unlike his other writings.

Although Abdul Rahman raised a large sum for his family's liberty, he would leave with his wife Isabella aboard the Harriet for Liberia, leaving behind his children and grandchildren. While he was there, he focused his efforts on freeing other members of his family with whom he could not travel. Abdul Rahman died on July 6, 1829 before ever reuniting with his children and grandchildren. However, at least eight or more of his family members arrived in Africa between the years 1830 and 1835. Like Ayyub, there is no proof that Abdul Rahman kept his promises to his patrons of spreading Christianity amongst other Muslims. However, Andrew Marschalk claims that Abdul Rahman strictly practiced Islam throughout 1828. This belief that Abdul Rahman strictly, if not freely, adhered to Islam in his final days in America differs from Omar ibn Said's circumstances. 


\section{Omar Ibn Said (1770-1864)}

Omar Ibn Said, or Morro, as his white patrons called him, was born in 1770 in a West African region called Futa Toro. In the year 1807 at the age of thirty-seven Omar was enslaved and taken to Charleston, South Carolina. After about two years of enslavement Omar escaped to Fayetteville, North Carolina where he was captured and jailed. While he was imprisoned, Omar caught the attention of his new owner, General James Owen, after he filled "the walls of his room [jail cell] with piteous petitions to be released, all written in the Arabic language" ("Uncle Moreau"). He not only captured the attention of General Owen and his family but that of the locals, because as one contemporary notes, he "wrote in a masterly hand, writing from right to left, in what was to [local observers] an unknown language" ("Prince Moro"). The mystery surrounding Omar's unique ability to write in another language also led to his being called an "Arabic scholar" (The Life of Omar ibn Said 4) and like Abdul Rahman Ibrahima he was portrayed as an Arab. Calling Omar an Arabic scholar may not be an exaggeration when comparing Omar's narrative to other African Muslim slave narratives. He proves that his knowledge of Arabic is more extensive than his counterparts'.

There are large differences between Omar's Arabic writing and that of Abdul Rahman in that Omar's Arabic is clear, legible, and more accurate. This may be due in large part to their difference in background: while Abdul Rahman was a warrior and came from a royal family, Omar studied Arabic and the Qur'an for twenty-five years and subsequently became a teacher of both. Although there are minor grammatical errors in Omar's writing, he is able to recall the spelling and context of his writing. In fact, unlike Abdul Rahman, Omar is able to write the actual "Lord's Prayer" perhaps from the Arabic Bible acquired for his use by Francis Scott Key when he was believed to have converted to Christianity. Ala Alryyes writes that there is no 
evidence of Omar ever truly converting and quotes Allan Austin as observing, "Omar was regularly willing and able to reassure all Christians that he was a true convert, as he often wrote in Arabic what he called "The Lord's Prayer" and the "Twenty-Third Psalm" (The Life of Omar ibn Said 4). Interestingly, there is a moment where one of Omar's writings is mislabeled as "The Lord's Prayer" when in actuality it is Surat Al-Nasr, the English translation on the back of his writing says, "He is 88 years of age + a devoted Christian." Whether or not Omar's conversion was legitimate is debatable, but like Abdul Rahman he may have opened himself up to the Bible due to an affinity with its teachings since both men understood the similarities between the Bible and the Qur'an.

The first of Omar's writings was written in 1828 and incorrectly labeled the "Twentythird Psalm." It is actually one of Omar's first writings of "The Lord's Prayer" which he would have been able to copy from the Bible he was given. However, it seems that Omar has almost memorized it perfectly as his writing indicates few errors. Another version found in a manuscript dated 1840 seems to be an updated version of the first. Here, Omar has included at the top, "In the name of God the Merciful, the Compassionate. Peace be upon Muhammad" while the first reads, "And this is how you pray." This is just one of the many indicators that Omar firmly retained his Muslim identity. 

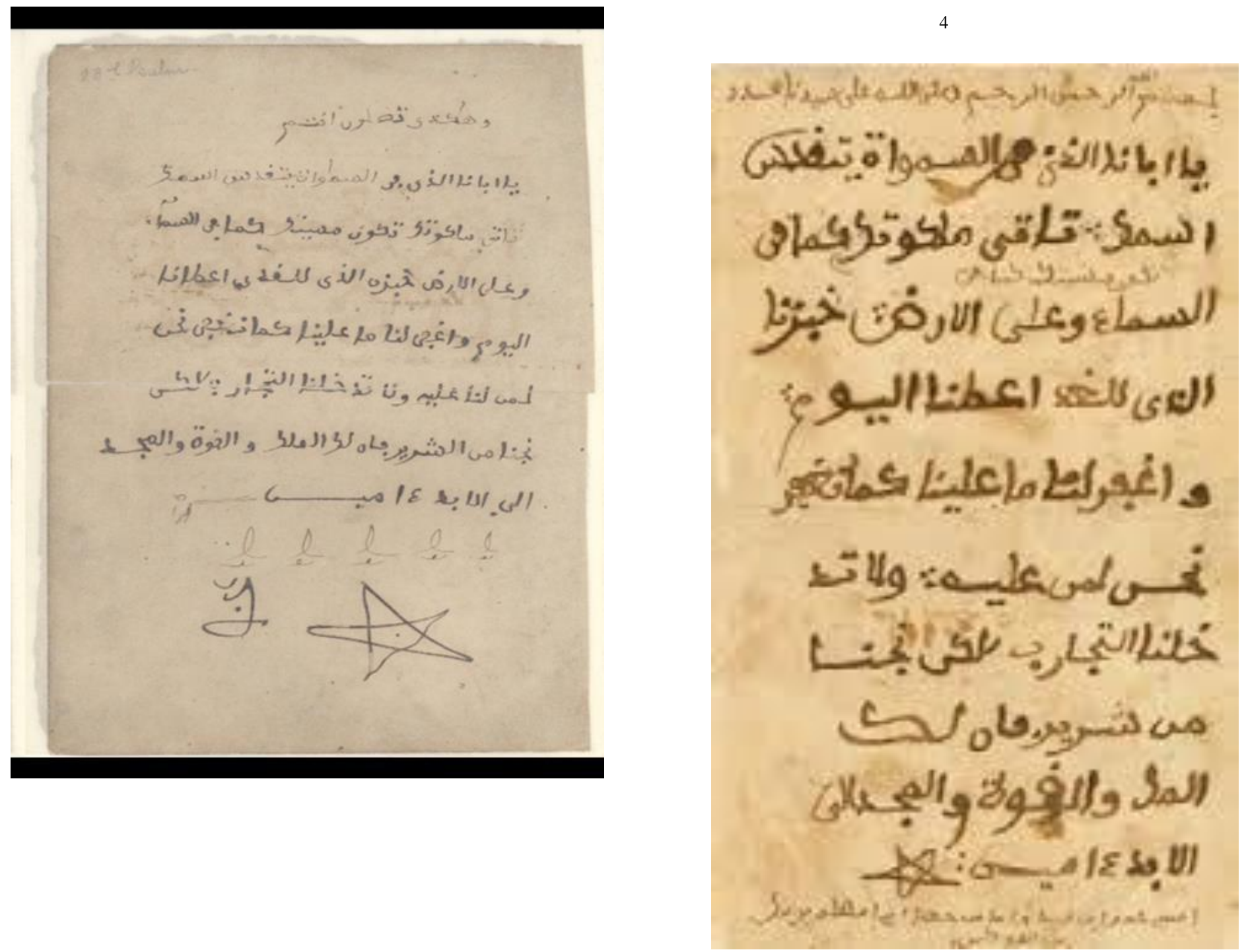

3 “The Lord's Prayer" written by Omar ibn Said in 1828, mislabeled as the "Twenty-third Psalm."

${ }^{4}$ The second version of the Lord's Prayer written by Omar ibn Said and found in a manuscript dated 1840. 


\begin{tabular}{|c|c|}
\hline $\begin{array}{c}\text { Transliteration of Omar's } \\
\text { "Lord's Prayer" }\end{array}$ & $\begin{array}{l}\text { Correct transliteration of } \\
\text { the "Lord's Prayer" }\end{array}$ \\
\hline $\begin{array}{l}\text { Line 1: Bismillah ar-Rahman } \\
\text { ar-Raheem, Salah Allahu ala } \\
\text { Sayideena Muhammad. } \\
\text { Line 2: Ya Abbana Al-lethi } \\
\text { fisamawat yataqadas } \\
\text { Line 3: Ismak, Ta'ti } \\
\text { malakootak kama fee } \\
\text { Line 4: Latakun mashyatak } \\
\text { kama fee } \\
\text { Line 5: As-sama'a wa ala al } \\
\text { ard khubzana } \\
\text { Line 6: Al-lethi laqad } \\
\text { A'ateena Al-yowm } \\
\text { Line 7: Waghfir lana wa } \\
\text { Alayna kama naghfir } \\
\text { Line 8: Nahnu limen alayhi, } \\
\text { wa la tad } \\
\text { Line 9: Khulna al-tajarub, } \\
\text { lakin najeena } \\
\text { Line 10: Min sharer, la in laka } \\
\text { Line 11: Al-Mulk, wal quwa, } \\
\text { wal mejid e-la } \\
\text { Line 12: Al-abed. Ameen. }\end{array}$ & $\begin{array}{l}\text { Line 1: Abana al- lethi fee } \\
\text { as-samawat, leyataqadas } \\
\text { Line 2: Ismak leya'ti } \\
\text { malakootak, latakun } \\
\text { mashya'taka } \\
\text { Line 3: Kama fee as-sama'a } \\
\text { kathaleeka ala al-ard } \\
\text { khubzana } \\
\text { Line 4: Kafana a'ateena } \\
\text { alyowm waghfir lana } \\
\text { thanoobena } \\
\text { Line 5: Kama naghfir nahnu } \\
\text { aydun lilmuthneebeen ilayna } \\
\text { wa la } \\
\text { Line 6: Tedkhilna fee } \\
\text { tajreebatin, laken najeena } \\
\text { min al-shareer } \\
\text { Line 7: La in laka al-Mulk } \\
\text { wal quwa wal mejid e-la } \\
\text { abed. } \\
\text { Line 8: Ameen. }\end{array}$ \\
\hline
\end{tabular}

In the same manuscript dated in 1840, Omar writes the "Twenty-third Psalm", beginning with the same opening as his updated version of the "Lord's Prayer," "In the name of God the Merciful, the Compassionate. Peace be upon Muhammad." Although an Arabic Bible was made 
available for Omar, his version of the "Twenty-third Psalm" seems to change the location of certain words in each line. The first two lines are underlined in red to indicate Omar's inclusion of Islamic writing. It appears that Omar rearranged the words of some of the verses while also omitting other verses. Since Omar was more familiar with Arabic than the other slaves, it seems that he arranged it according to his understanding, while also changing the tenses of some of the words to make them possessive. In this way, Omar tries to find a connection with the words by writing them as if they were exclusively for him. Whether he is trying to imitate his former connection with the Qur'an is indeterminate, but one can argue that his rearranging of the verses mimics the structure of Qur'anic scripture.

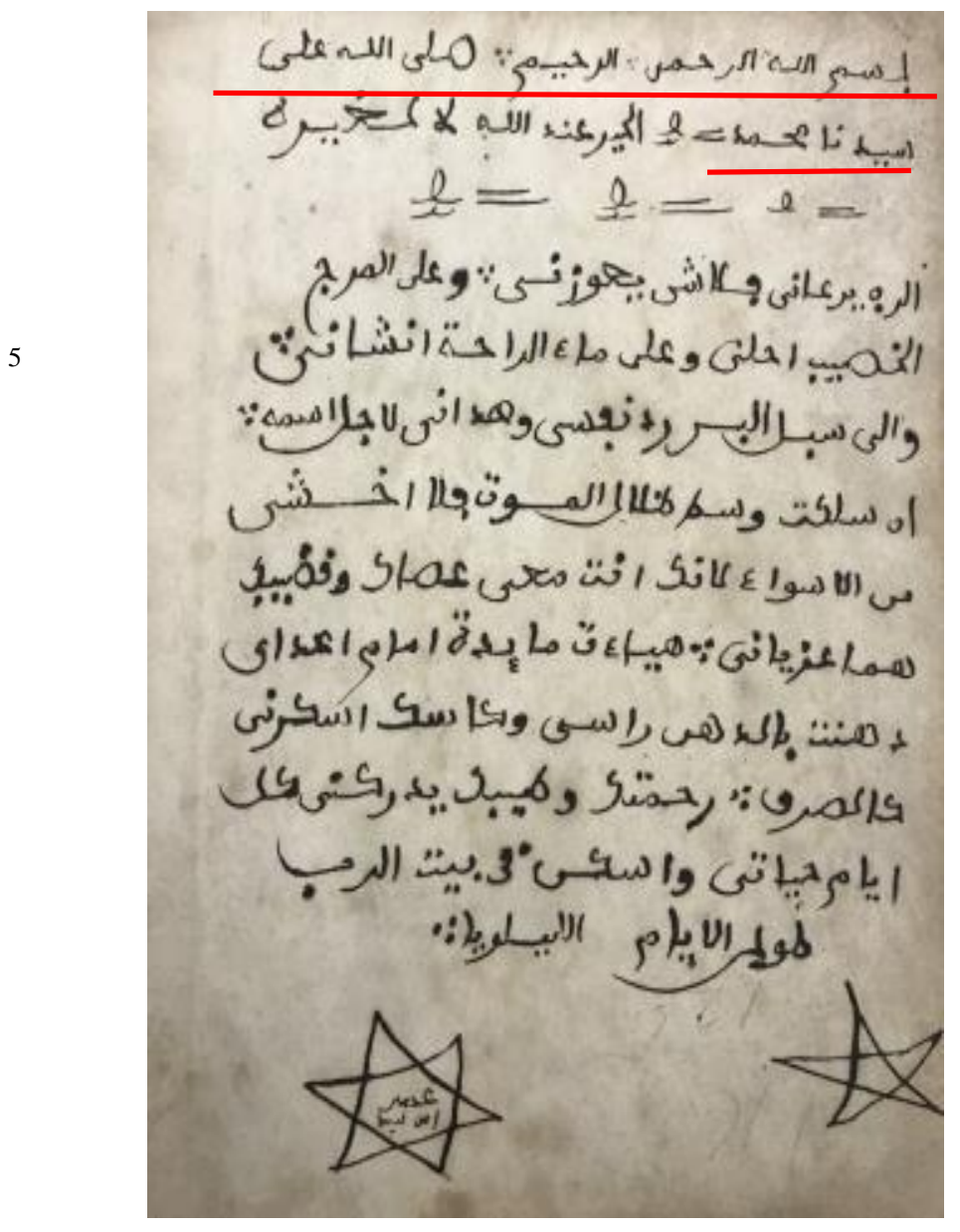

\footnotetext{
${ }^{5}$ The "Twenty-third Psalm" found in a scrapbook, 1840.
} 


\begin{tabular}{|c|c|}
\hline $\begin{array}{l}\text { Transliteration of Omar's } \\
\text { "Twenty-third Psalm" }\end{array}$ & $\begin{array}{l}\text { Correct Transliteration of the } \\
\text { "Twenty-third Psalm" }\end{array}$ \\
\hline $\begin{array}{l}\text { Line 1: Bismillah ar-Rahman, } \\
\text { ar-Raheem. Salla Allahu ala }\end{array}$ & $\begin{array}{l}\text { Line 1: Mezmoor la Dawud. } \\
\text { Ar-rab ra'ee fa la ya oozani } \\
\text { shay'a. }\end{array}$ \\
\hline $\begin{array}{l}\text { Line 2: Sayidna Muhammad. } \\
\text { Alkhayr ind Allah la le ghayrihi }\end{array}$ & $\begin{array}{l}\text { Line 2: Fee mara khudur } \\
\text { yarbudni. Illa meyah ar-raha } \\
\text { yuridni. }\end{array}$ \\
\hline $\begin{array}{l}\text { Line 3: Al-Rab yarani fa la } \\
\text { shay'a ya oozani. Wa ala almarj }\end{array}$ & $\begin{array}{l}\text { Line 3: Yarid nefsee. Yahdeeni } \\
\text { illa subul albir min ajal ismuh. }\end{array}$ \\
\hline $\begin{array}{l}\text { Line 4: Al khaseeb ahla wa ala } \\
\text { ma'a alraha ansha'ani. }\end{array}$ & $\begin{array}{l}\text { Line 4: Eyda itha sarat fee } \\
\text { wadee dhul al-mawt la akhaf } \\
\text { shara la'anaka enta ma ee. } \\
\text { Asaka wa akazak hemma ya } \\
\text { izyanenni. }\end{array}$ \\
\hline $\begin{array}{l}\text { Line 5: Wa illa albir reda nafsee } \\
\text { wa hadani le ajal ismuh. }\end{array}$ & $\begin{array}{l}\text { Line 5: Tarteb qadammi } \\
\text { ma'eeda tajah madda yaqee. } \\
\text { Masahet bid dihin rasee. Kasee } \\
\text { reya. }\end{array}$ \\
\hline $\begin{array}{l}\text { Line 6: In (?) seleket wasut } \\
\text { dhalal al-mawt fala akhsha }\end{array}$ & $\begin{array}{l}\text { Line 6: Innama khayr wa } \\
\text { rahma yeteba anee kulla ayyam } \\
\text { hayyati waskun fee bay tar-Rab } \\
\text { illa medd al-ayyam. }\end{array}$ \\
\hline \multicolumn{2}{|l|}{$\begin{array}{l}\text { Line 7: Min al-sawa'a le- eneka } \\
\text { anta ma ee, asaka wa qadeebuka }\end{array}$} \\
\hline \multicolumn{2}{|l|}{$\begin{array}{l}\text { Line 8: Hemma ezyani. Heya'at } \\
\text { ma'eeda ammam a'a da'ee }\end{array}$} \\
\hline \multicolumn{2}{|l|}{$\begin{array}{l}\text { Line 9: Dahentu bid duhun raasi } \\
\text { wa ka'asak eskurni }\end{array}$} \\
\hline \multicolumn{2}{|l|}{$\begin{array}{l}\text { Line 10: Kalsaraf. Rahmatak wa } \\
\text { teebuka yedrukni kulla }\end{array}$} \\
\hline \multicolumn{2}{|l|}{$\begin{array}{l}\text { Line 11: Ayyam hayyati, } \\
\text { waskun fee bayt al-Rab }\end{array}$} \\
\hline $\begin{array}{l}\text { Line 12: Tool al-ayyam. } \\
\text { Aliluyah. }\end{array}$ & \\
\hline
\end{tabular}


A manuscript given to a minister's daughter by James Owen in 1857 was supposed to be the "Lord's Prayer," as indicated by the English handwriting on the back of the manuscript, but it is actually Surah 110 from the Qur'an. Surah 110 or Surat An-Nasr translates to "The Divine Help" and is believed to be the last chapter of the Qur'an revealed to the Prophet Muhammad. Although Omar makes a few spelling errors in his version, he writes down all the verses in the correct order. However, he does include extra verses that are not found in this chapter. The inclusion of those verses does not add any unique meaning to the chapter but may have a more personal significance. Many of Omar's admirers believed him to be a Christian, but as Austin Allen writes in his essay "Contemporary Contexts for Omar's Life and Life" that after translating one of Omar's manuscripts in 1904, Princeton Professor R.D. Wilson observed that "Uncle Moro still retained a little weakness for Mohammed" (The Life of Omar ibn Said 145) because he opened the "Twenty-third Psalm" with "Bismillah" (In the Name of God). The added verses that Omar included are highlighted in red and underlined in the photo,

\section{Transliteration of Omar's Surat An-Nasr:}

Line 1: Itha ja an-nasr min Allah

Line 2: Wa fatih, qareeb wa bashir almu'

Line 3: Meeneen wa rayta an-nasa

Line 4: Yedkhuluna fideeni

Line 5: Allahi afwaja fasabih

Line 6: Bihamdi rabika

\footnotetext{
${ }^{6}$ Omar's written version of Surat An-Nasr, 1857.
}

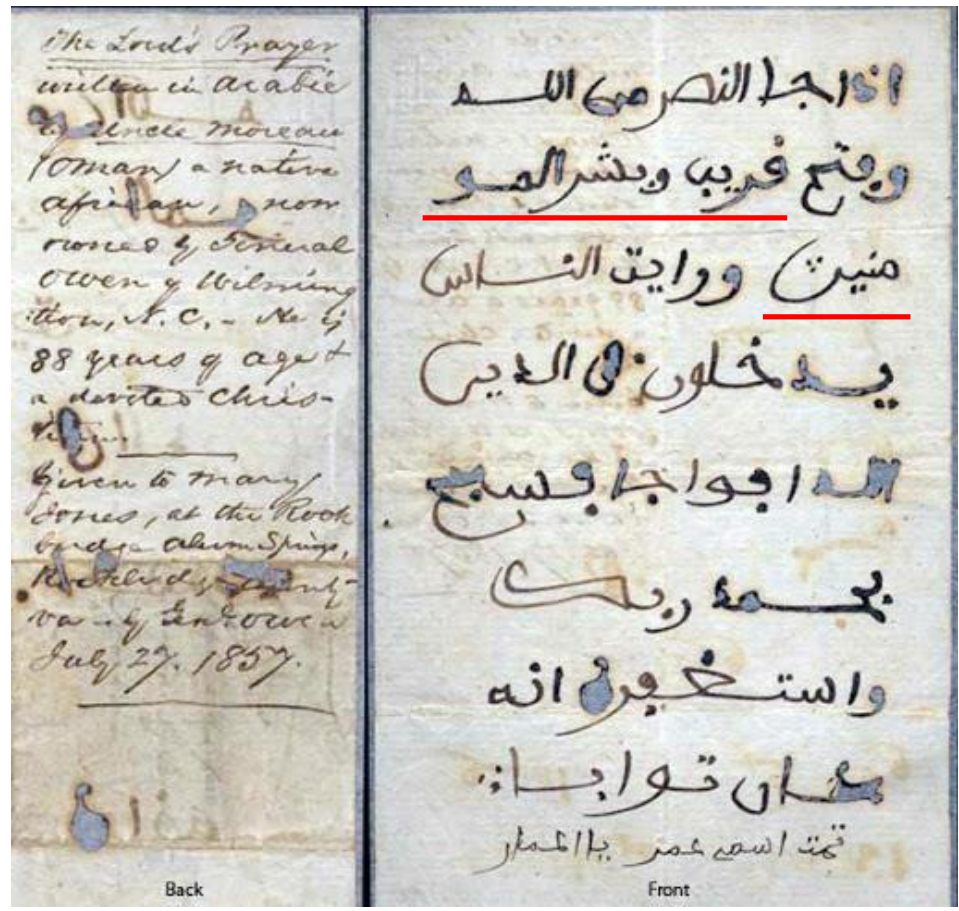


Line 7: Wa staghfiru inahu

Line 8: Kana tawaba

\section{Correct transliteration of Surat An-Nasr:}

Verse 1: Itha ja'a nasrul-laahi walfath

Verse 2: Wa ra-aitan nasa yadkhuloona fee deenil laahi afwajaa

Verse 3: Fasabbih bihamdi rabbika wastaghfirh, innahoo kaana tawwaaba

Besides the few grammatical errors that Omar makes in the beginning and the added verses that translate to, "near" and "good tidings to the believers," his copy of the surah is accurate enough for us to read today. His gift of the Arabic Bible unwittingly served a dual purpose for Omar in that it helped him preserve the Arabic he already knew therefore preserving his Muslim identity. Unlike Abdul Rahman Ibrahima, he did not have to resort to sand writing. Instead, he was fortunate enough to have a text that would allow him to retain his ability to recall the Qur'an. By merely interacting with Arabic, he maintained his Arabic literacy and a sense of Islamic identity. His version of this surah adds to the theory that Omar did not actually convert and that his inclusion of those added verses may be a reminder to himself that God is near and that he will be rewarded for being steadfast in his religion.

In fact, this would not be the last piece of Qur'anic Arabic Omar would write. Below is a

presumed Christian prayer dated January $8,1845^{7}$ which is actually comprised of Surahs 104 and 106 or Surat Al-Humazah and Surat Quraish. The first line that Omar writes until the three dots

\footnotetext{
${ }^{7}$ Presumed Christian prayer written by Omar is actually Qur' anic scripture, image below.
} 
he has drawn, indicated by a red circle, are a praise to God who has created all creation in order to worship Him.

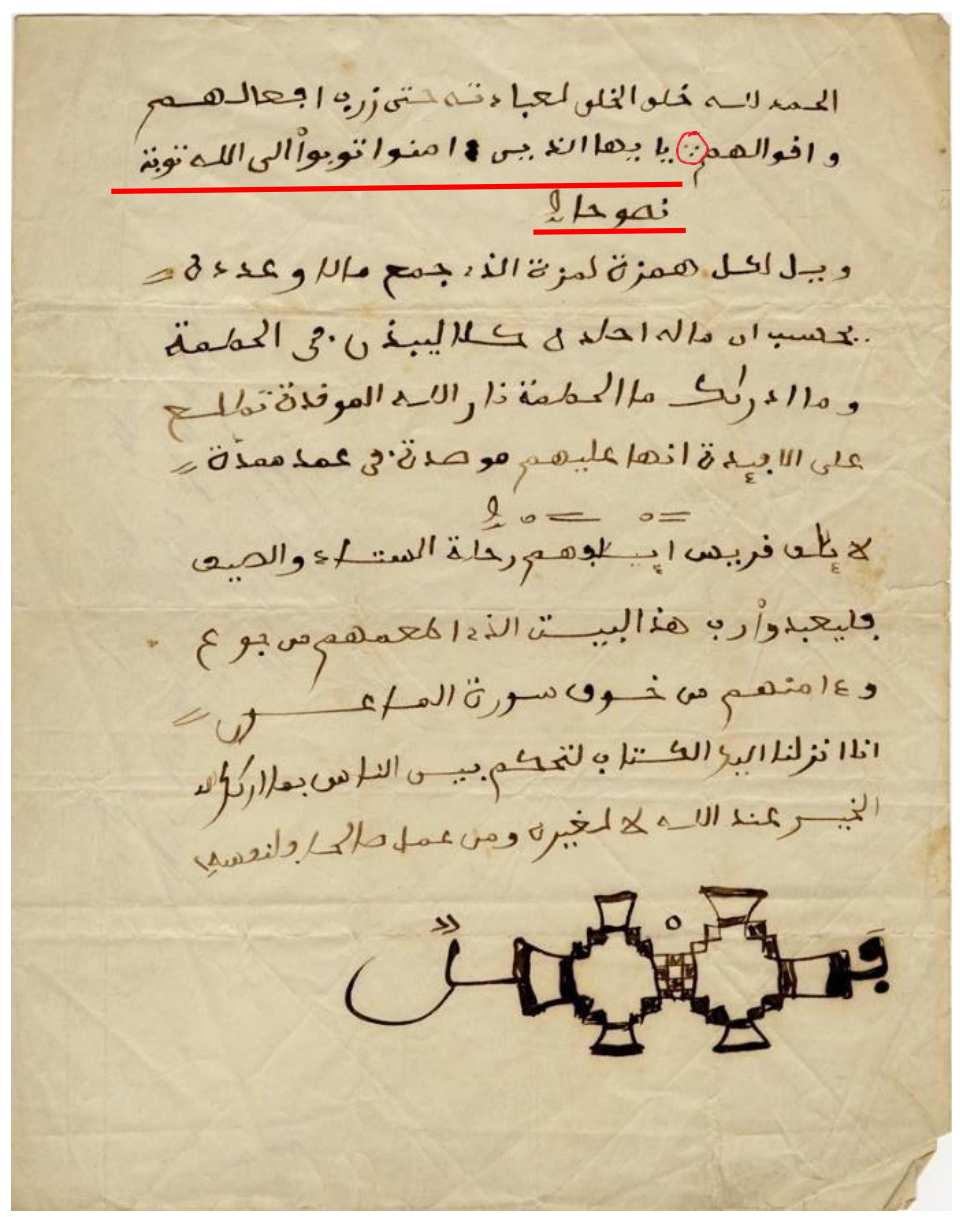

7. Surahs 104 and 106 written by Omar Ibn Said

Following those three dots, Omar has included part of verse eight from Surat At-Tehreem, indicated above by red lines, which translates to, "O believers, Turn to Allah (God) in sincere repentance." Omar's choice of Qur'anic chapters or verses to include appear to be significant as he wrote the entirety of Surat Al-Mulk in his autobiography. Scholars speculate as to why he chose to write it out entirely, but Ala Alryyes argues that Omar chose it as a kind of prologue (The Life of Omar ibn Said). Alryyes writes, “Omar's choice of this sura, or Qur'anic chapter, seems deliberate and highly significant in the context of a slave narrative" (18). He continues, 
“The noun al-mulk comes from the tripartite Arabic root, malaka, meaning both 'to own' and to 'have dominion.' The title of the sura is, therefore, the perfect allusion to slavery: absolute power through ownership. Omar seems to refute the right of his owners over him, since only God has the mulk, the power and the ownership" (The Life of Omar ibn Said 18). It appears that Omar did something similar with the inclusion of part of this verse from Surat At-Tehreem and used it as another prologue to the two shorter surahs he includes in his 1845 manuscript.

Surat Al-Humazah does the same thing that Alryyes argues al-Mulk does, but it speaks to specific characteristic of slavery: amassing and hoarding wealth. Since slave owners profited off the backs of their slaves, it appears Omar is calling for them to repent for their sinful behavior. In fact, Omar's counterpart, Abdul Rahman Ibrahima, explicitly says to his owners and patrons, "the [New] testament very good law; you [Christians] no follow it; you no pray often enough; you greedy after money. [If] you good man, you join the religion. [But] you want more land; more neegurs; you make neegur work hard, make more cotton" (Prince Among Slaves 81). Surat Quraish speaks to the unbelieving tribe of Muhammad, calling them to believe in Muhammad's message. Again, this surah alludes to repentance for the preservation of one's soul. So, the part of verse eight that Omar decided to include is a fitting prologue to the two shorter chapters. Omar could have also hoped to see his owners become Muslim, as slim as that possibility was. In fact, Omar praises his owners in his 1831 autobiography, writing, "I continue in the hands of Jim Owen, who does not beat me, nor calls me bad names...During the last twenty years I have not seen any harm at the hands of Jim Owen" (The Life of Omar ibn Said 79). He also praises his children, "This is a good generation. Tom Owen and Nell Owen had two sons and one daughter...This generation is a very good generation...O, people of America, do you have...such a good generation that fears Allah so much?" (The Life of Omar ibn Said 79). Despite his praise 
and easy life as a slave, Omar still despised the institution of slavery. Because he could not communicate the same way Abdul Rahman did, he resorted to writing out chapters from the Qur'an that would speak for him, allowing Arabic to work as a means of rebellion against the many people who were fascinated by his supposed exoticism.

At the end of Surat Quraish Omar adds the words Surat Al-Ma'oon, (surah 107), indicated below with a black line, which is the title of the surah that comes after Surat Quraish. In fact, the intricate design at the bottom of the manuscript is the word that sounds like, "Feel," indicated by a red circle, which is the Arabic word for elephant and happens to be surah 105 that comes after Surat Al-Humazah. The order in which Omar places the chapters is strange; it does not necessarily indicate that Omar has forgotten the surahs, but readers of this manuscript and his other writings get the sense that he remembers the chapters from the Qur'an well enough without having a physical copy of it. This reiterates the theory that the Arabic Bible helped Omar retain the Arabic he grew up learning and teaching before his enslavement. However, the assumption that Omar wrote the Arabic word for "elephant" ("Feel") may not be accurate. I later discovered a manuscript written by Omar in $1840^{8}$, Omar concludes his writing with the same presumed word, "Feel," indicated by a black circle. Although Omar omits the two dots that are usually at the bottom of the ' $y$ ' sounding Arabic letter, , there are other manuscripts that indicate Omar has made this error frequently. Thus, my earlier theory that Omar included "Feel" because it fell into the sequential order of the Qur'an in his previous manuscript appears to be incorrect. Despite it coincidentally fitting into the manuscript, the manuscript written in 1840 is

\footnotetext{
8 “The Lord's Prayer" written by Omar in 1840, ending with the same presumed word "Feel" which translates to "Elephant."
} 
the "Lord's Prayer." Therefore, what the encircled words below mean remains a mystery. They may be an added design at the end of his writing, as Omar includes many in other manuscripts.

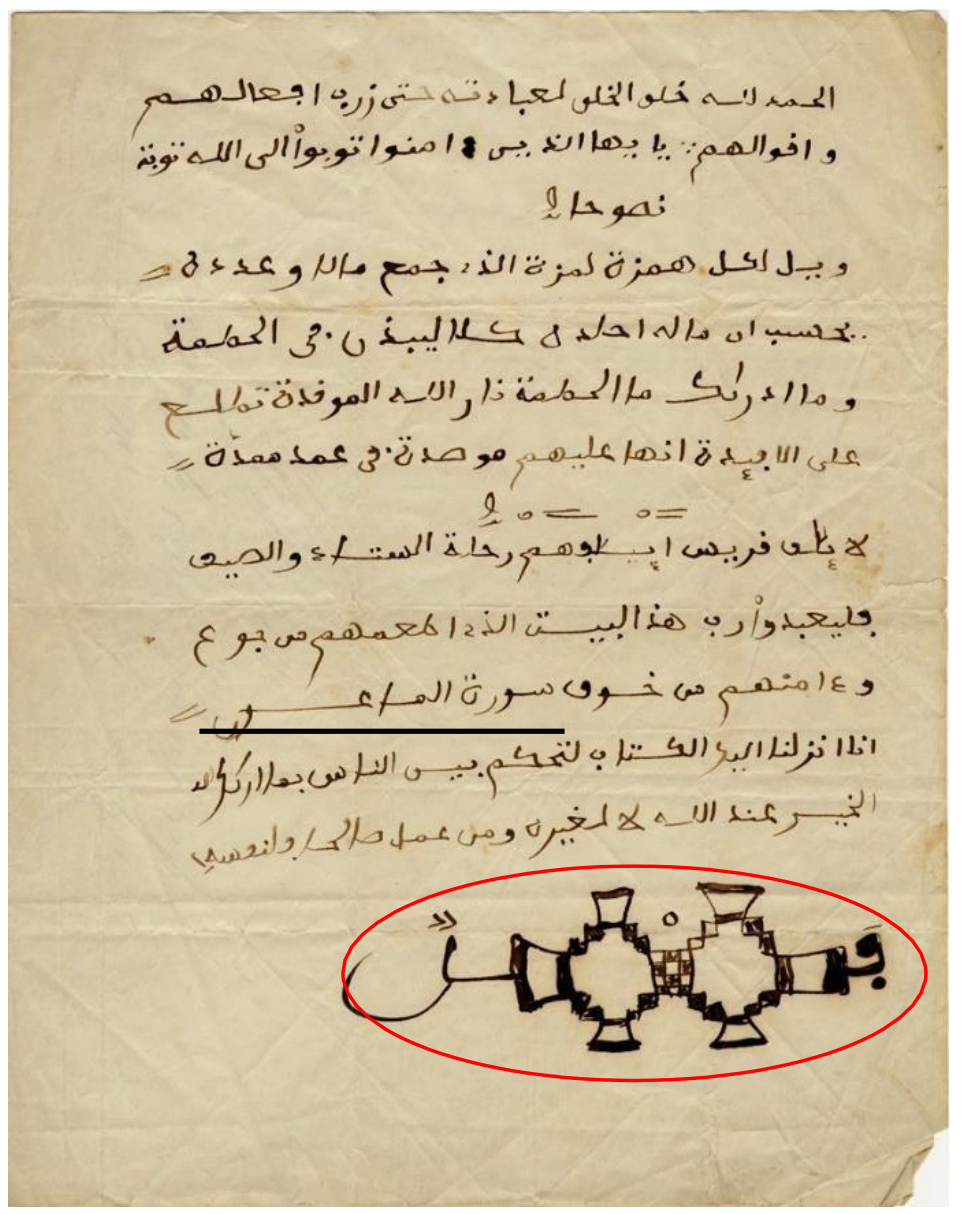

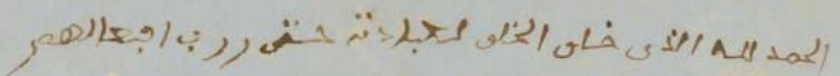

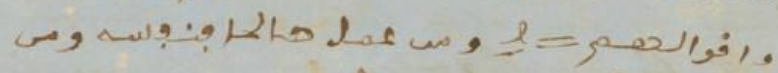

$$
\begin{aligned}
& l=10 \text { txis }
\end{aligned}
$$

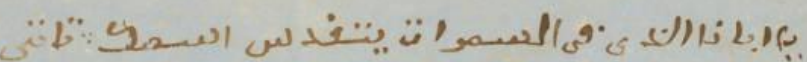

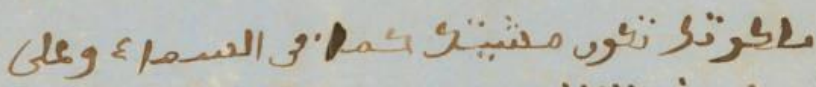

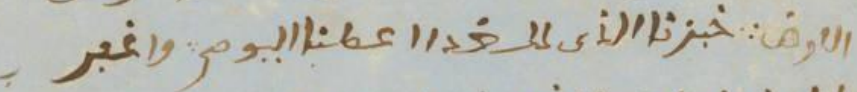

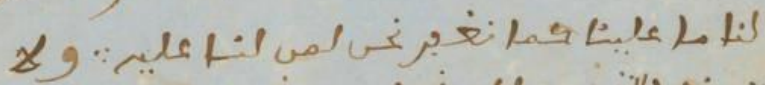

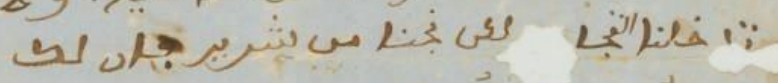

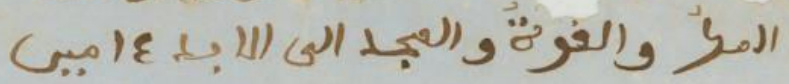

$$
\begin{aligned}
& \$ \\
& 4(120
\end{aligned}
$$

8. The Lord's Prayer written by Omar in 1840 . 
While Omar adopted a new style of Arabic writing, intertwining Biblical and Qur'anic scripture throughout his manuscripts, he also included English words written in Arabic, particularly, the names of his owner and other members of the Owen family. Below, Omar writes in his $1828^{9}$ manuscript, which is mislabeled as the "Lord's Prayer," the names of the Owen family. A transliteration of their names indicates that Omar adopted a Southern accent in his Arabic, omitting any emphasis on the last syllable of Betsy's name, writing her name in Arabic as "Betseh."

\section{Transliteration of the names of the Owen Family:}

Line 1: Sayyid Ismuh Jeem Ooween

Line 2: Betseh Ooween. Thomas Ooween. Marsa Ooween.

Line 3: Meereh Ooween (Possible nickname for Miriam Owen).

Line 4: Shifee Ooween. Joon Ooween. Mar-ket Ooween.

Line 5: Leeseh Ooween.

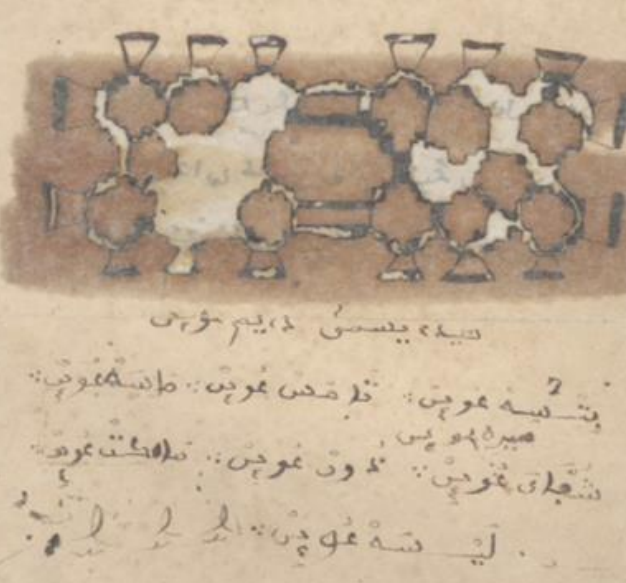

\section{Presumed Translation:}

Line 1: Master's name is Jim Owen

Line 2: Betsey Owen (Jim Owen's wife). Thomas Owen. Martha Owen.

Line 3: Meery Owen (Possible nickname for Miriam Owen).

Line 4: Sophia Owen. John Owen. Margaret Owen.

\footnotetext{
${ }^{9}$ The names of the Owen family written by Omar ibn Said in 1828, mislabeled as "The Lord's Prayer."
} 


\section{Line 5: Lisa Owen.}

Omar writes the names of the Owen family the way he has heard them especially since it appears that he has written the nickname of Miriam Owen. The average Arabic reader would notice that the Arabic letters change somewhat the pronunciation of the names when read, overextending certain syllables where they would not otherwise be extended in English. This adoption of a Southern accent within his Arabic writing is seen again in an 1853 letter written to the Taylor family.

10

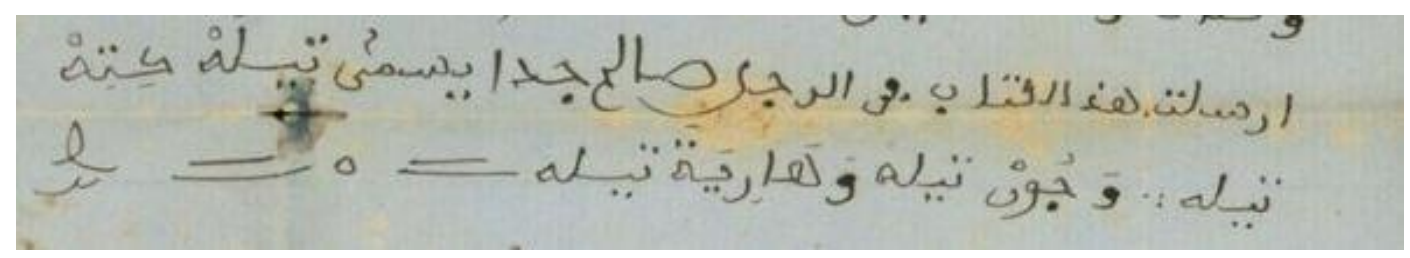

Transliteration of a portion of the letter written by Omar to the Taylor family:

Line 1: Arsaltu hathalkitab fee rajul saleh ismuhu Teela, Kitteh

Line 2: Teela. Wa Joon Teela, wa Haree'et Teela.

Translation of a portion of the letter written by Omar to the Taylor family:

Line 1: I sent this writing with a righteous man named Taylor, Kitty

Line 2: Taylor. And John Taylor, and Harriett Taylor.

Instead of using the Arabic alphabet for ' $r$ ' at the end of the Taylor last name, Omar opted to use the Arabic alphabet that makes a silent ' $h$ ' sound at the end of a word which would have been the

${ }^{10}$ Names of the Taylor family written by Omar in an 1853 letter. 
way he heard the last name being said. This small adoption authenticates Omar's writing while also bringing together his various linguistic identities.

Teaching slaves to read and write during their enslavement was not only illegal but dangerous for slave owners. They knew all too well that educating a slave would cause dissension and opposition to authority. Slaves who came to America already literate in Arabic were different, however. Their Arabic literacy and character, which attributed to their backgrounds as Muslims, transformed their lives as slaves in the South and helped them during their time as slaves. The pages from Omar's autobiography I will be examining are six, nine, ten, twelve, and thirteen. These five pages speak to Omar's identity, his time spent in slavery, his life before enslavement, his literacy, and his supposed conversion.

The first manuscript of Omar's that warrants interest is his letter to a Sheikh Hunter, who is possibly "Reverend Eli Hunter, from New York, who is known to have toured North Carolina for the ACS (American Colonization Society) in 1839" (The Life of Omar ibn Said 17). Omar writes, "From Omar to Sheikh Hunter, you have asked me to write my life. I cannot write my life because I have forgotten much of my talk and the talk of the Arabs" (The Life of Omar ibn Said 59) It's ironic that Omar tells Sheikh Hunter that he cannot write his life and that he has forgotten much of his Arabic as his fluency in the language was preserved after so many years and can be accurately read today. Even more interesting is that Omar separates himself from Arabs by referring to Arabic as something that is not originally his. In this same letter to Sheikh Hunter, Omar describes his education, "I sought knowledge in Bundu and Futa with a Sheikh called Mohammad Said, my brother, and Sheikh Suleiman Kimba and Sheikh Jebril Abdal. I continued seeking knowledge for twenty-five years, [then] I came to my place [and stayed] for six years" (The Life of Omar ibn Said 61). Omar has laid out his history before his audience and 
provides evidence that his education is something that is highly valued within his culture and family, and yet his explicit mentioning of his birthplace in Fut Tur and where he acquired his schooling in his letter to Eli Hunter is ignored. Instead of focusing on his extensive education and the time it took for him to acquire it, they credit his supposed Arab-ness. In fact, Omar's patrons may have been indirectly influenced by Thomas Jefferson's Notes on the State of Virginia. He writes, "that in memory they are equal to the whites; in reason much inferior, as I think one could scarcely be found capable of tracing and comprehending the investigations of Euclid; and that in imagination they are dull, tasteless, and anomalous" and "But never yet could I find that a black had uttered a thought above the level of plain narration; never see even an elementary trait of painting or sculpture" (1095). As I stated earlier in both Abdul Rahman and Omar's narratives, white patrons could not grasp that they were interacting with well-educated West Africans who contradict Jefferson's observations about black slaves and thus resorted to de-Africanizing by Arabizing them.

In pages nine and ten Omar writes about his life before being enslaved while also detailing the religious activities he performed such as praying, fasting, and giving charity. $\mathrm{He}$ opens manuscript nine by saying, "Oh, people of North Carolina; Oh, people of South Carolina," almost as though calling to them to hear him, his story, and his life. These opening lines indicate that Omar knows his writing will be shared with others. He knows that his owners and patrons are fascinated by the mystery surrounding his personal history, thus he is in a position, unlike the slaves around him, to tell his story in his own words. In fact, he ends his tenth and eleventh manuscript with the same plea, including America in the latter manuscript, while also praising the Owen family for their generosity and care towards him. Within pages nine and ten, Omar raises some questions about whether or not he truly converted to Christianity. He writes: 
Jim with his brother read from the Bible that Allah is our Lord, our Creator, and our Owner and restorer of our condition, health and wealth by grade and not duty. [According?] to my ability, open my heart to the right path, to the path of Jesus Christ, to a great light. Before I came to the Christian country, my religion was/is the religion of Mohammad, the prophet of Allah, may Allah bless him and grant him peace." (The Life of Omar ibn Said 67)

Omar is aware that there are similarities between Christianity and Islam, but there is ambiguity when he writes about having been a Muslim. His mentioning of opening his heart to Jesus contradicts the sentence he writes after, which is indicated by red lines below. Alryyes provides his own translation but includes "was/is" when Omar refers to the religion he follows. If Omar were to speak about the religion he once followed in the past tense he would have included the word, كان pronounced "kana" which translates to "was." However, a literal translation of what Omar says is, Before I came to the Christian country, my religion is the religion of Mohammad the messenger of Allah, may Allah bless him with peace. The structure of Omar sentence is odd, yet declarative. Another indication that his conversion may not have been thorough is that fact that Omar refers to America as a Christian country. Omar knows that he is in America, as he mentions America in his eleventh manuscript, but if he were truly converted, assimilated, and Christian, he would not separate himself by repeatedly referring to it as such.

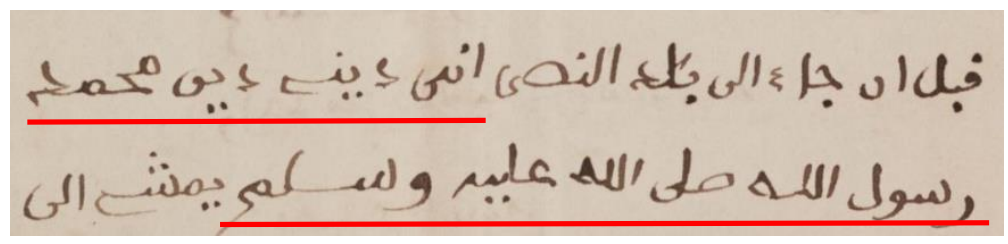

Omar's twelfth manuscript page further reinforces the theory that he may not have been a true convert. He writes, "I am Omar, I love reading the book, the great Qur'an (The Life of Omar 
ibn Said 71). He then talks about General Owen and his wife both reading the Bible to him and concludes with what can only be described as a prayer. Omar writes, "Open my heart to the Bible, to the path of righteousness" (The Life of Omar ibn Said 73). This is the second time Omar writes this line which I believe displays a sense of anxiety on his part. He is in a culture and society much different from his own, knowing that the Bible is a Christian book, a book that is mentioned in the Qur'an associated with Jesus Christ. However, he also is aware that his owners and the rest of North Carolina are not Muslim. Since Omar's extensive education covered both Arabic and the Qur'an, he would believe (as Muslims do) that the Bible, Qur'an, and Torah are all books revealed by the same God. Although this would be a change for Omar and despite the verses being different, he would identify part of the Bible, such as "The Lord's Prayer" and the “Twenty-third Psalm," and embrace it from a Muslim perspective. Thus, he would not be renouncing his identity as a Muslim but would be supplementing it with the Bible. This is confirmed by the fact that Omar continues to refer to the Qur'an throughout his autobiography and would transcribe entire chapters from it.

Omar retains his identity as a Muslim through a kind a mimicry that engages in a dual perspective. Homi Bhabha writes in his essay titled, "Of Mimicry and Man: The Ambivalence of Colonial Discourse" that mimicry can be defined as a "representation of a difference that is itself a process of disavowal. Mimicry is thus, the sign of a double articulation; a complex strategy of reform, regulation, and discipline, which 'appropriates' the Other as it visualizes power” (3). With Omar's many references to his owner's reading the Bible to him and gifting him with his own Arabic Bible, he is repeating and proclaiming what is expected of him possibly to retain the favor of those around him. However, Arabic allows him the opportunity to create some distance between these repeated ideas. Thereby, giving readers the impression that he has become an 
American Christian, but upon closer analysis, he never declares himself a Christian but underscores his basic Islamic beliefs. In the thirteenth page he writes,

First, [following] Mohammad. To pray, I said: "Praise be to Allah, Lord of the Worlds; the Compassionate, the Merciful; Sovereign (Malik) of the Day of Judgement; It is You we worship, and to You we turn for help; Guide us to the straight path; The path of those whom You have favored with grace; Not of those who have incurred Your wrath; Nor of those who have strayed. Amen." And now, I pray [I say] in the words of our Lord Jesus the Messiah: "Our Father, who art in heaven, hallowed be thy name, thy Kingdom come. Thy Will be done, on earth as it is in Heaven. Give us this day our daily bread and forgive us our trespass against us, and lead us not into temptation but deliver us from the evil one for thine is the Kingdom, the power, and the glory for ever and ever. Amen." (The Life of Omar ibn Said 75)

Omar enacts a kind of double-ness in his writing, relating Christianity and Islam by using the Bible to engage with Islamic ideas and beliefs. He speaks in the past tense when referring to the way he used to pray as a Muslim and then speaks in the present tense when referring to his current condition. Although it appears that he admits to a conversion by switching between the past and present, it is not evidence enough to suggest that it was genuine. In fact, just as Abdul Rahman Ibrahima did before him, he utilizes the "Lord's Prayer" and the opening chapter $A l$ Fatiha, as two texts that are similar enough in translation and principle. From Omar's and Abdul Rahman's points of view, they are not abandoning their Islamic upbringing but utilizing a religious text to their advantage. As both Omar and Abdul Rahman display different levels of their knowledge of Arabic, they were subjected to some degree of Arabization. Interestingly, 
Omar's literacy is possibly second to Ayyub bin Suleiman and much more advanced than Abdul Rahman's, but no effort was ever made to free him and return him to Africa. 


\section{Chapter 3:}

\section{Orientalizing and Arabizing African Muslim Slaves}

It is fair to say that the reason these men, particularly Abdul Rahman and Omar, were subjected to some degree of Arabizing because of preconceived ideas about Africans. Although both their patrons and eventual friends knew that they came from West Africa, they could not understand how their manners and education aligned with this part of their identity. Perhaps their Arabic literacy made it easier for them to Arabize them, but I believe that this Arabization of their identities did not occur because of Southern slave owners who were sometimes both uneducated and illiterate, but from educated politicians and well-traveled men. In the case of Abdul Rahman he had by chance crossed paths with Dr. Coates Cox who stayed with Abdul Rahman and his tribe after Cox's ship had sailed without him. It's only after their meeting in the market where Abdul Rahman was selling his vegetables that any real effort to free Abdul Rahman was made. Dr. Cox knew Abdul Rahman's background well and may have been his only shield from being Arabized, however Cox would die before Abdul Rahman gained his freedom.

The influence that his white patrons had over his identity led to his Orientalization, but Abdul Rahman was aware that by allowing this process of Orientalizing to occur, it would better his chances at gaining his freedom. The most prominent example of his Orientalizing is the costume he was provided with, an outfit bought on his behalf without his consultation. I refer to his clothing as a costume because Abdul Rahman was playing a part bestowed upon him and orchestrated by his patrons. Scholars such as Munawar Ali Karim and Terry Alford both refer to this costume as being Arabian Nights-esque, referring to Arabian Nights, a compilation of folk tales set in the Middle East during the Islamic Golden Age that was translated into English between 1706 and 1721. In fact, many of the illustrations found in today's versions of the Arabian Nights 
were drawn by Westerners. Below is an example of one of those images similar to the description of the costume Abdul Rahman was provided.

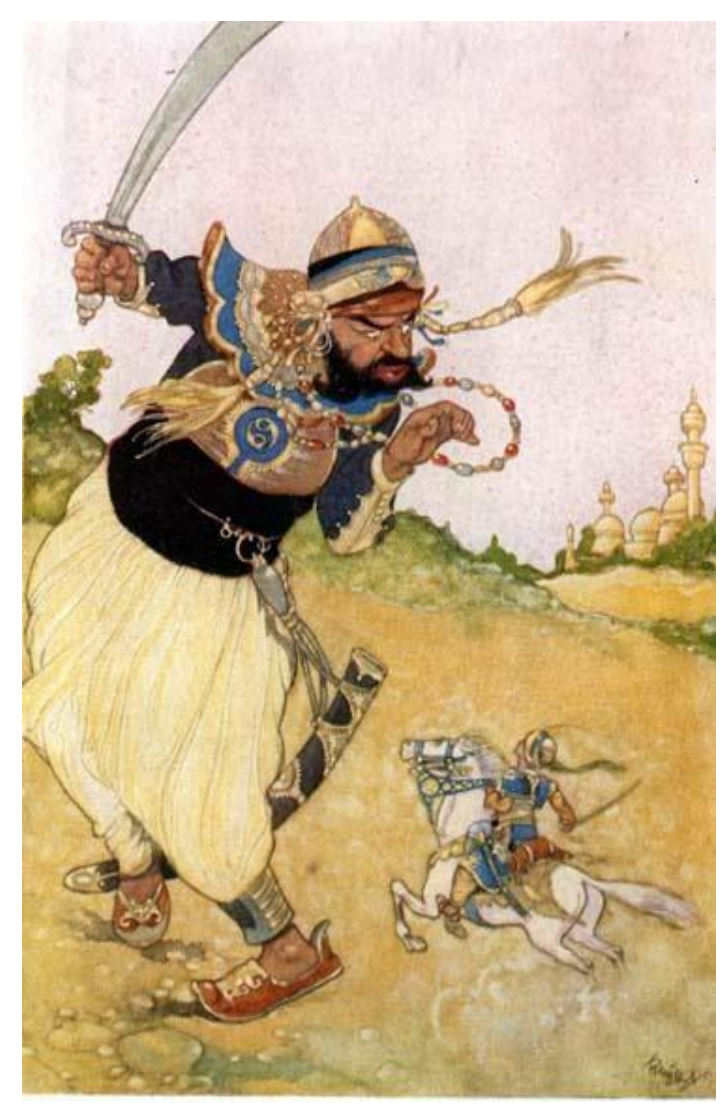

H.J. Ford, 1898

The attempt at dressing him in luxurious clothing follows a trope about the East that was well established even during the time of Shakespeare's writing. Arguably, the images associated with the East, or in this case, Moors or Arabs derives from the fantasy and sensuality mistakenly associated with Islam. For example, Thomas Bluett compares his interaction with Ayyub to his view of Muslim Turks: "He [Ayyub] did not believe in a sensual paradise, nor many ridiculous and vain traditions, which pass current among the generality of the Turks" (Liberty's Jihad 136). Thomas Bluett and Ayyub's new friends had preconceived ideas of Muslims, but their views were not as blatantly projected on to him as they were onto Abdul Rahman. Despite Cyrus Griffin's 
objection to Abdul Rahman's costume, he propagated Abdul Rahman's supposed Moorish identity by writing a series titled, "Prince, the Moor." In one of his pieces he writes,

Prince is a Moor. Of this, however, his present appearance suggests a doubt. The objection is that "he is too dark for a Moor and his hair is short and curly." It is true such is his present appearance; but it was materially different on his arrival in this country. His hair was at that time soft and very long, to a degree that precludes the possibility of his being a negro. His complexion, too, has undergone a change. Although modern physiology does not allow color to be a necessary effect of climate, still one fact is certain that a constant exposure to a verticle sun for many years, together with the privations incident to the lower order of community, and an inattention to cleanliness, will produce a very material change in the complexion. It is true his lips are thicker than usually, those of the Moor; but the animal frame is not that of the negro; his eyes, and, in fact, his entire physiognomy is unlike that of any negro we have ever seen. And if the facial angle be an infallible criterion the point is established, his being equal and perhaps greater, than most of the white. (Servants of Allah 98)

By dedicating this series to the belief that Abdul Rahman was a Moor, Griffin echoes Edward Said's theory that assigning meaning to foreigners or Others make these assignments valid (Orientalism 54).

Omar ibn Said's Arabic literacy is second to Ayyub's, having studied Arabic and the Qur'an for twenty-five years and eventually becoming a teacher himself. He was the oldest of the men at the age of thirty-seven to be captured and taken to America. Throughout his forty years in North Carolina, Omar's Arabic literacy continued to fascinate the people around him. He too, would find himself exoticized. Ala Alryyes writes that an article from 1825 in the Christian 
Advocate reads, "[Moro] was a prince in his own country...[and] his intercourse with the Arabs has enabled him to write and speak their language with the most perfect ease" (The Life of Omar ibn Said 32). Likewise, The Wilmington Chronicle wrote in 1847 that, "Monroe, the servant of General Owens...belonged to the Foulah [Fulbe] tribe in Africa [who] are known as the descendants of the Arabian Mahomedans who migrated to Africa...Monroe is an Arab by birth, of royal blood" (32). The refusal to acknowledge literacy and education amongst Africans emphasizes the desire for many white patrons to uphold the stereotype that they are incapable in their indigenous societies of a higher understanding of language and literacy. Omar's nickname, "Moro," raises another point about the Arabization of his identity. Although he is never explicitly called a "Moor," it can be assumed that the people of North Carolina, viewed Omar the same way Abdul Rahman's townspeople viewed him.

Ayyub had escaped the process of de-Africanization unlike his subsequent counterparts. perhaps because of his time. It does not appear that Orientalized ideas of Arab speakers applied to African slaves in the eighteen century, but Ayyub was certainly still an Other. Perhaps it was Ayyub's sophistication and ability to make his new friends understand Islam in a way that challenged their Orientalized ideas that allowed him to pass through this experience as an African. Thomas Bluett obviously made a connection between sensuality and Islam, but Ayyub's interpretation and practice was different than that of the Turks, who were the primary examples when it came it came to Islam in the eighteenth century. Even so, Orientalist ideas may not have attracted much attention when Ayyub found himself in England. Ideas of exoticism though clearly present according to Thomas Bluett, had not yet taken hold on perceptions of African Muslims. 
If the patrons and acquaintances of Ayyub, Abdul Rahman, and Omar had known about the emphasis on education and literacy in Islam, their inability to reconcile their African identities with this fact may have helped them escape exoticizing or Orientalizing. However, because of their common interactions with slaves in America and the laws that prohibited teaching, reading, and writing to slaves, these three men challenged those ideas of African inferiority to the point where their owners and patrons could only reject their Africanness and create false representations of them. Their Arabization follows a common trope that is still present in the twenty-first century, which is that the writing of Arabic and the majority population of Islam is comprised of Arabs. This misplaced idea of Islam being mostly practiced by Arabs coupled with sensual and romantic representations led to a total redirecting of these men's identities. 


\section{Chapter 4:}

\section{The Absence of Muslim Slave Writings in American and African American Literature}

The lack of recognition and inclusion of Muslim slaves in both American literature and the American slave narrative genre persists. Ala Alryyes writes in A Muslim American Slave: The Life of Omar ibn Said that Omar's Arabic narrative challenges a "literary template" traditionally followed in the American slave narrative genre (13). This template that Omar and other slaves deviated from, whether delivered through writing or oration, sought to stick to the same facts of slavery which did not include an interest in the backgrounds and personal histories of slaves. The fact that they wrote their narratives in Arabic speaks to the only history they had as slaves in the Antebellum South and is an important contribution to American slave narratives. Florence Marfo's “African Muslims in African American Literature” explores the characteristics of Muslim slave narratives where she argues that the first issue is that of authorship. Here, she begins with Ayyub's story as told through Thomas Bluett's account. The mere fact that Ayyub did not write it himself leaves it at risk of being influenced by a white man who has the power to manipulate it any way he wants. She writes that this is "one of the impediments to its inclusion in the genre of African American slave literature..." (Marfo 1213). However, I argue that Ayyub was very much in control of his narrative because of the way in which Bluett represents him as both a Muslim and an African. Ayyub would, however, write a letter to his father explaining his situation and later three copies of the Qur'an with his own introduction. Obviously, the Arabic would be out of reach from manipulation, but if it were written in English, perhaps it would be at risk.

Further investigation calls for a comparison between one of the most famous American slaves, Frederick Douglass, and his earlier counterparts. The second issue is that they are not 
generational slaves and that their writings occurred during their enslavement and not after. Marfo continues by writing that this becomes a problem when considering Muslim slaves' place in American literature and American slave narrative genre. Furthermore, she contends that referring to African Muslims slaves as "African American" is an issue as well (1214) and that their return to Africa seems to determine whether or not their writings deserve to be discussed in classrooms and scholarship. I agree that African Muslim slaves' writings are personal narratives that do not necessarily meet the criteria of a slave narrative because they do not explicitly speak out against the institution of slavery, but I do believe that their writing is still a unique contribution to the genre because they avoid outside influence. When it comes to Omar ibn Said, who wrote the longest personal narrative of the three men, Marfo views his writing as a "praise of the rectitude of one of his owners, Jim Owen, and his family...Said seems more than reconciled to his status as Jim Owen's property...Even at the dawn of the abolition of the slave trade in the United States, Said falls short of indicting the system of slavery..." (1215). It seems then that the exclusion of Muslim slaves also has to do with whether or not they have written about the deplorable institution of slavery. What Marfo and other scholars fail to consider when they do discuss African Muslim slave narratives is that Arabic literacy is what separates them from other American slaves and was a contributing factor to either their better treatment or eventual manumission.

Later, Marfo makes an interesting case for Muslim inclusion in the American slave narrative genre because a slave's humanity was determined by his literacy, it made "writing the sole avenue to humanity" (1219). Although slaves were barred from learning how to read and write, some would teach themselves, and would escape like Frederick Douglass. I reiterate that the inability to write or communicate in English posed a more difficult challenge for Muslim 
slaves who could do neither. Their literacy in a language other than English is quite remarkable because they were able to gain the sympathy of white patrons who would eventually dramatize their histories and help them. Their remarkable differences are what make them stand out when compared to other slaves in America and that the circumstances surrounding their eventual freedom or, in the case of Omar, easier life as a slave, is owed to their Arabic literacy. Including them in both American literature and the American slave narrative genre acknowledges their contribution to the development of black cultural identity in the United States. Although their narratives do not follow the conventional slave narrative, these men's writings influenced their environments and displayed their resilience in an unfamiliar world. 


\section{Conclusion}

These narratives and writings add depth to both American history and American literature because of the way they have been woven into the fabric of American society for over fourhundred years. Although Ayyub, Abdul Rahman, and Omar were exoticized because of their Arabic literacy, it was this very quality that both empowered them and posed a threat. Arabic as a threat to the institution of slavery can be seen in the reluctance on the part of both Thomas Jefferson and John Quincy Adams to actively participate in liberating the slaves with whom they interacted. Their inability to connect and understand Arabic threatened a system they actively participated in and profited from . By examining the level of literacy of each man and by scrutinizing their writing, I have discovered that mimicry played a role in at least Omar ibn Said's autobiography. By participating in mimicry, Omar's writing has earned the same level of attention given to conventional slave narratives. Although they are in Arabic, and in contradiction to what some scholars believe, their writings actually challenged the conditions of slavery through the carefully chosen surahs they wrote.

Although examining their writings requires a degree of further understanding in both Arabic and Islam, they are well worth including in the larger conversation of the slave narrative genre. In this way, the Qur'an is utilized as a guide that summarizes what they are going through as slaves, which is actually a direct conversation with their oppressors. As I have outlined earlier, even to their slave owners and patrons, the Qur'an is the most recognizable form of Arabic. This allowed white writers a window into interpreting these men's writing directly and was a form of reclaiming their African identities. While their African identities were rejected and replaced by Arab ones, framing these men as Eastern Others introduces a more complex element compared to the traditional slave narrative writing. It creates an entirely new question about identity that 
requires further investigation. Although Arabic allowed these men to live easier lives as slaves, they still had to endure elements of slavery, which influenced their writing. The influence upon their writing would not solely be based on the surahs they wrote, but also by the way their masters spoke. In Omar's case particularly, we see that his Arabic adopts a Southern accent. This further supports my argument that slavery did influence their writing, though not in the same way traditional slave narratives may have been. Despite their experiences varying from the dominant population of American slaves, I argue for a focus on the power of literacy and what these narratives will do for the future of our understanding of the slave narrative genre regardless of what language they employ. In sum, they introduce new areas of exploration that deviates from a traditional reading of a slave narrative while simultaneously expanding the very criteria that dictates what a slave narrative can be. 


\section{Bibliography}

“A Qur'an Written by Ayuba Suleiman Diallo.” British Library, https://www.bl.uk/pressreleases/2015/october/british-library-launches-major-west-africaexhibition?inViewer=imgID7bd8ce0e-65c8-450f-a044-bd5b00b6d38f.

“African Muslim Enslaved in America." Innovative Minds, http://www.inminds.com/genocideday2010.php\#c7.

“African Muslims in Early America.” National Museum of African American History \& Culture, 21 Feb. 2017, https://nmaahc.si.edu/explore/stories/collection/african-muslims-early-america.

Alford, Terry. Prince Among Slaves: The True Story of an African Prince Sold into Slavery in the American South. Oxford University Press, 1977.

Alryyes, Ala. A Muslim American Slave: The Life of Omar ibn Said. The University of Wisconsin Press, 2011.

“Arabic Verse with an Unusual History.” New York Historical Society: Museum \& Library, 9 Mar. 2016, https://blog.nyhistory.org/arabic-verse-with-an-unusual-history/.

Austin, Allan D. “Contemporary Contexts for Omar's Life and Life.” A Muslim American Slave: The Life of Omar ibn Said. The University of Wisconsin Press, 2011.

Bhabha, Homi. “Of Mimicry and Man: The Ambivalence of Colonial Discourse.” 1984. PDF file.

Bismillahirrahmanirrahim. Diyanet Haber, Turkey. https://www.diyanethaber.com.tr/kur-an-ikerim/besmele-bismillahirrahmanirrahim-h12327.html.

"Black Muslims in Early America." Oxford Academic, https://medium.com/history-uncut/blackmuslims-in-early-america-8bc869cc7f6a. 
CritiqueZ. "The Opening—Surah Al-Fatihah." Pinterest,

https://www.pinterest.com/pin/382524562100063660/

Curtis, Edward. Muslims in America. Oxford University Press, 2009.

Dabovic, Safet. "Displacement and the Negotiation of an American Identity in African Muslim

Slave Narratives". Dissertation, Stony Brook University, 2009. ProQuest Dissertations \& Theses Global.

Diouf, Sylviane. Servants of Allah: African Muslims Enslaved in the Americas. New York University, 1998.

Douglass, Frederick. Narrative of the Life of Frederick Douglass. The Anti-Slavery Office, Boston: 1845.

Einboden, Jeffrey. Jefferson's Muslim Fugitives: The Lost Story of Enslaved Africans, Their Arabic Letters, \& an American President. Oxford University Press, 2020.

Gomez, Michael. "Muslims in Early America”. A Muslim American Slave: The Life of Omar ibn Said. The University of Wisconsin Press, 2011.

Hoare, William. Portrait of Ayuba Suleiman Diallo. 1734. Wikipedia Commons, https://en.wikipedia.org/wiki/Ayuba_Suleiman_Diallo\#/media/File:William_Hoare_of_Bath__Portrait_of_Ayuba_Suleiman_Diallo,_(1701-1773).jpg.

Ibrahima, Abdul Rahman. Abdul Rahman's Autobiography. 1828. Wikipedia Commons, https://commons.wikimedia.org/wiki/File:Abdulrahman_Ibrahim_Ibn_Sori_1.jpg. 
---.The Lord's Prayer. 1828. Wikipedia Commons,

https://commons.wikimedia.org/wiki/File:Abdulrahman_Ibrahim_Ibn_Sori_2.jpg.

Inman, H. Abduhl Rahhahman. 1834. Wikipedia Commons, https://en.wikipedia.org/wiki/Abdulrahman_Ibrahim_Ibn_Sori\#/media/File:Ibn_Sori.jpg.

Jefferson, Thomas. Notes on the State of Virginia. 1785. PDF file.

Judy, Ronald A.T. (Dis)Forming the American Canon: African-Arabic Slave Narrations and the Vernacular. 1993. PDF file.

Karim, Munawar Ali. Liberty's Jihad: African Muslim Slaves and the Meaning of America. Diptote Books, 2019.

"Letters by Ayuba Suleiman Diallo." British Library, https://www.bl.uk/collection-items/ayubasuleiman-diallo-letter.

Lovejoy, Paul E. “Freedom Narratives’ of Transatlantic Slavery.” Slavery \&Abolition, vol. 32, no.1, 2011, pp. 91-107.

Marfo, Florence. “African Muslims in African American Literature.” Callaloo, vol. 32, no. 4, 2009, pp. 1213-1222.

"National Museum of African American History and Culture: Muslims in the New World." Black History \& Culture, , https://blackhistory938.wordpress.com/2017/06/20/national-museum-ofafrican-american-history-and-culture-muslims-in-the-new-world/. 
“ 'Oh ye Americans:' The Autobiography of Omar ibn Said.” National Humanities Center Resource Toolbox: The Making of Africa American Identity, vol.1, 2018, http://nationalhumanitiescenter.org/pds/maai/community/text3/religionomaribnsaid.pdf.

Said, Edward. Orientalism. Random House, 1978.

Spalding Gentlemen's Society. Sgsoc.org.

“Spartanburg Manuscript.” Department of English: Northern Illinois University, Arabic Slave Writings and the American Canon, https://www.niu.edu/arabic-slave-writings/spartanburgmanuscript/index.shtml.

"Surat al-Nasr From the North Carolina Collection, University of North Carolina at Chapel Hill." Documenting the American South, https://docsouth.unc.edu/nc/omarsaid/support3.html.

"The Arabian Nights Entertainment." Classics Illustrated, http://classicsillustrated.com/arabian/contents.html.

"The Life of Omar ben Saeed, called Morro, Fullah Slave in Fayetteville, N.C. Owned by Governor Owen." Library of Congress, https://www.loc.gov/resource/amedsaid1831.dw042/?sp=1\&st=grid.

“The Lord's Prayer.” Online Book of Common Prayer, https://www.bcponline.org/General/paternoster.html.

Uncle Marian, a slave of great notoriety of North Carolina. 1850. Wikipedia Commons, https://en.wikipedia.org/wiki/Omar_ibn_Said\#/media/File:Uncle_Marian_-_crop_\&_levels.jpg. 
“Writing Sample from Uncle Moreau.” New Hanover County Public Library, https://cdm16072.contentdm.oclc.org/digital/collection/p15169coll8/id/28/rec/34. 


\section{Appendix of Terms}

Surah-Chapter

Ramadan - Holy month of fasting

Tashkeel - Phonetic guides used to inform the pronunciation of words

Bismillah ar-Rahman ar-Raheem - In the name of God, the most Compassionate the most

Merciful

Meghrebi - A style of Arabic script developed in North Africa

Al-Fatiha - The opening chapter of the Qur'an

Salah - Physical act of worship, performed by a Muslim

- Pronounced "kana" 